\title{
SOKOLSKÉ JEDNOTY ČECHŮ Z VOLYNĚ
}

\author{
Ondřej Štěpánek
}

\section{The "Sokol" Associations of Czechs from Volyně}

\begin{abstract}
The fundamental purpose of this article is to contribute towards mapping out the hitherto largely neglected development and significance of one of the most important aspects of the community life of emigrants from the Czech Lands settled in the area of Volyně - known as the Volyně Czechs. The article deals with their Sokol Physical Education Associations, from their initial foundation in the 1870s to the activities of the Czechs of Volyně in the aftermath of World War II subsequent to their re-emigration to Czechoslovakia. Particular attention is devoted to the inter-war period, during which the Associations achieved their greatest expansion in Volyně. They helped not only to develop physical fitness but also towards the upbringing of the youth, strengthening their Czech consciousness and sense of belonging to their historical homeland. Despite the fact that their activities would later become complicated and indeed rendered impossible by the Polish and Soviet authorities, the Sokol Associations left an important mark - still remembered in various places within the region, and to which present-day associations hark back.
\end{abstract}

Keywords: Sokol - Volyně Czechs - Sokol Associations - Volyně - Physical Education

Contact: Mgr. Ondřej Štěpánek, Oddělení novodobých českých dějin Národního muzea, Vinohradská 1, 11000 Praha 1; e-mail: ondrej.stepanek@nm.cz

Základním cílem této stati je přispět ke zmapování vývoje a společenského významu jedné z částí spolkového života emigrantů z českých zemí na území Volyně, tzv. volyňských Čechů. Text se zabývá jejich sokolskými tělovýchovnými jednotami, přičemž největší pozornost je věnována období mezi světovými válkami, kdy došlo k jejich největšímu rozmachu. Začátkem 20. let 20. století byla Volyň rozdělena na polskou a sovětskou část, a i díky tomu přispěli ke zkoumání historie tamní sokolské komunity zejména v posledních letech také polští i ukrajinští badatelé. Práce polských výzkumníků však nepojednávají o tématu komplexně, zabývají se především polskými sokolskými jednotami a těch v obcích s početným českým zastoupením se dotýkají jen okrajově nebo je opomíjejí úplně. Mezi poslední odborné texty napsané na toto téma patří článek $Z$ dziejów Towarzystwa Gimnastycznego ,, Sokót” okręgu wotyńskiego (1922-1939). ${ }^{2}$ Řadu velmi cenných informací o vývoji sokolských jednot ve východní části oblasti, které nejsou v česky psané literatuře dostupné, přinesla ukrajinská publikace vydaná v roce 2015 s názvem Historie gymnastického spolku ,, Sokol“ "na Volyni. ${ }^{3}$
V české literatuře se téma sokolských jednot Čechů na Volyni objevovalo jen minimálně, a to zpravidla v souborných publikacích, kde však byly uvedeny i leckteré zásadní nepřesnosti. Některé informace o českých Sokolech se objevují například v prvních dvou dílech trrídílných Dějin volyn̆ských Čechi̊ od historika Jaroslava Vaculíka. Téma se zpravidla okrajově objevuje též leckde v memoárové literatuře. Ze spolků volyňských Čechů se dosud v soudobé literatuře dočkaly zvýšeného zájmu v souhrnnější práci pouze sbory dobrovolných hasičů, které jsou tématem monografie reemigranta z oblasti Václava Kačírka Češti hasiči na Volyni vydané v roce 2004 .

Jedním z podnětů pro vznik tohoto příspěvku bylo zpřístupnění unikátního původního pramene - digitalizované Malé kroniky Sokolské tělocvičné jednoty ve Straklově Českém. ${ }^{4}$ Tuto pamětní knihu ručně psal od počátků straklovské jednoty až do faktického zániku ${ }^{5}$ její jednatel, místostarosta a později i vzdělavatel - učitel Alexandr Křivka. Podle svého zápisu v ní tak činil ,na di̊kaz opravdové oddanosti sokolské myšlence “. V kronice se objevují dosud nepublikované

1 Předložená studie vznikla za finanční podpory Ministerstva kultury v rámci institucionálního financování dlouhodobého koncepčního rozvoje výzkumné organizace Národní muzeum (DKRVO 2019-2023, oblast 12.II.a)

2 Teresa Drozek-MEŁOLEPSZA - Eligiusz MEŁOLEPSZY, Z dziejów Towarzystwa Gimnastycznego „Sokół” okręgu wołyńskiego (1922-1939), in: PRACE NAUKOWE Akademii im. Jana Dlugosza w Częstochowie, Czestechowia 2018.

3 Історія гімнастичного товариства «Сокіл» на Волині

4 K dispozici na webových stránkách Sdružení Čechů z Volyně a jejich přátel (http://www.scvp.eu/downloads/Mensi_Kronika_sokolske_telocvicne jednoty_v_Ceskem_Straklove.pdf).

5 V kronice pak následují události druhé světové války. 
informace dokládající mnohé zajímavé aspekty působení Sokolů v obcích volyňských Čechů ve 30 . letech 20 . století a kronika je doplněna i řadou fotografií. Mezi další důležité prameny patřila spolková periodika (Sokol, Věstník Sokol$s k y ́$ ), zprávy o činnosti sokolských jednot na Volyni v českých novinách (v Národních listech či Lidových novinách) a archiválie uložené v Národním muzeu. Také v Národním archivu jsou uloženy naprríklad stanovy některých českých jednot i další archiválie k tématu.

\section{Prvopočátky sokolských jednot na Volyni}

K samotnému vzniku Sokola došlo v Praze v roce 1862. Stejně tak do 60 . let 19 . století se datuje i prvotní hromadná emigrace obyvatel z českých zemí na Volyň, která ležela v tehdejším carském Rusku (dnes je součástí Ukrajiny). Emigrace ve zvýšené míře eskalovala od roku 1868. Na Volyň odcházeli lidé z českých zemí po skončení prusko-rakouské války především díky možnosti získání velice levné půdy, která byla mnohonásobně levnější i oproti půdě v zámořské Americe. Již v roce 1870 žilo v 67 volyn̆ských lokalitách přes deset tisíc emigrantů z českých zemí a jejich počet se nadále rychle zvyšoval. ${ }^{6}$ Po začátku imigrace tak vzrůstala potřeba sdružování nových osadníků, což s sebou přinášelo zakládání hudebních těles či různých spolků, např́iklad sborů dobrovolných hasičů. S tím souviselo i rychlé implementování sokolské myšlenky v novém prostředí a záhy tak i v něm vznikly první spolky Sokola, které patřily mezi první založené za rakousko-uherskými hranicemi.

$\mathrm{V}$ roce 1870 došlo do té doby $\mathrm{k}$ největšímu ročnímu nárůstu v počtu jednot sokolské organizace, ${ }^{7}$ mezi třiceti sedmi novými figurovaly i dvě jednoty v nově založených českých vesnicích na Volyni. Profesor Vaculík ve své přehledové publikaci umist'uje na základě článku ze 30. let minulého století zveřejněného v časopise Náš Buditel jednu do Mirohošti a druhou do obce Semiduby, kde v té době žilo 48 českých rodin a vlastnilo tam největší množství půdy ze všech obcí volyňských Čechů - 4000 jiter. $^{8}$ O činnosti Sokola v Semidubech v 19. století se nepodařilo dohledat žádné informace (jistě zde začal působit až na počátku 30. let 20. století). Podle jiných zdrojů informací se obě jednoty nacházely od Semidubů v nepř́liš vzdálené Mirohošti, ${ }^{9}$ přičemž jedna z nich byla spolkem jízdním. ${ }^{10}$ Obec Mirohošt' byla v tomto období se sto osmi rodinami druhou nejpočetnější českou vsí na Volyni. ${ }^{11}$ Akcí spojených se založením tamní sokolské jednoty, které proběhly v květnu $1870,{ }^{12}$ se zúčastnil i metropolita kyjevský a haličský, který přivezl volyňským sokolům prapor z Kyjeva a kladl důraz zejména na sokolské poslání. ${ }^{13}$ V srpnu téhož roku navštívil Mirohošt' volyňský generální gubernátor kníže Dondukov-Korsakov, který v rámci uvítání kráčel špalírem sokolů k nově zrrízené školní budově, během své návštěvy Volyně pak vyjádřil názor, že se mu sokolský oděv velmi líbí, a dal podobný zhotovit pro svého syna. ${ }^{14}$ Jeho syn Dmitrij se dokonce stal čestným starostou mirohošt'ské sokolské jednoty, ${ }^{15}$ které byl náčelníkem učitel Svoboda. ${ }^{16}$ Podle údajů z počátku roku 1871 v dobovém periodiku Sokol vykonávalo zaměstnání rolníka 32 členů jednoty z Mirohošti, což řadilo obec v tomto ohledu na druhé místo mezi více než stovkou tehdejších sokolských jednot v rámci tehdejší České obce sokolské (dále také ČOS). Celkově bylo v obou ruských sokolských jednotách podle statistického přehledu z počátku roku 1871 již 99 členů, kromě nejhojněji zastoupených rolníků např́iklad i šestnáct řemeslníků či živnostníků a sedm umělců. V periodiku je reflektována i procentuálně vysoká účast místních členů na cvičeních (více než padesátiprocentní a podle údajů dokonce stoprocentní ve spolku jízdním) ${ }^{17} \mathrm{O}$ aktivitě mirohošt'ského Sokola ve zbytku roku 1870 svědčí i značné množství dvaceti dvou cvičitelských porad, cvičení třikrát týdně, pět půldenních a pět celodenních výletů. ${ }^{18} \mathrm{~V}$ těchto ohledech patřil ke špičce v celé České obci sokolské. Národní listy v tomtéž roce zmiňují také sokoly z Kvasilova, kteří přijeli na koních do obce Hlinsk přivítat gubernátora oblasti a následně ho zřejmě doprovázeli ještě do města Rovno. ${ }^{19}$ Je otázkou, zdali se v tomto prrípadě jednalo o neoficiálně působící skupinu nebo o záměnu autorem článku s mirohošt’skou jízdní jednotou. První snaha o založení jednoty v Kvasilově podle jiného zdroje pochází z 80 . let 19 . století, kdy se již měnila politická situace a vliv měla rusifikační politika. „Občané tehdy chtěli využit př́jezdu volyňského gubernátora do Kvasilova, aby se mu představili v slavnostním kroji sokolském a požádali za dovolení, aby mohli založit sokolskou jednotu. Ale pokus ztroskotal. Gubernátor nechtěl červených košili ani vidèt a dlouho prý se nemohl uklidnit z rozčilení nad smělostí občanů, kteři mu vyjeli vstřic na konich v sokolském kroji. "20

Periodikum Sokol zmiňovalo založení sokolské jednoty také v obci Teremno, k čemuž mělo dojít v roce $1871 .^{21}$ $\mathrm{O}$ existenci Sokola v obci, kde žilo již v předchozím roce okolo osmdesáti českých rodin, ${ }^{22}$ svědčí i dobová zpráva v Národních listech o slavnosti ,přijímání poddanství“:

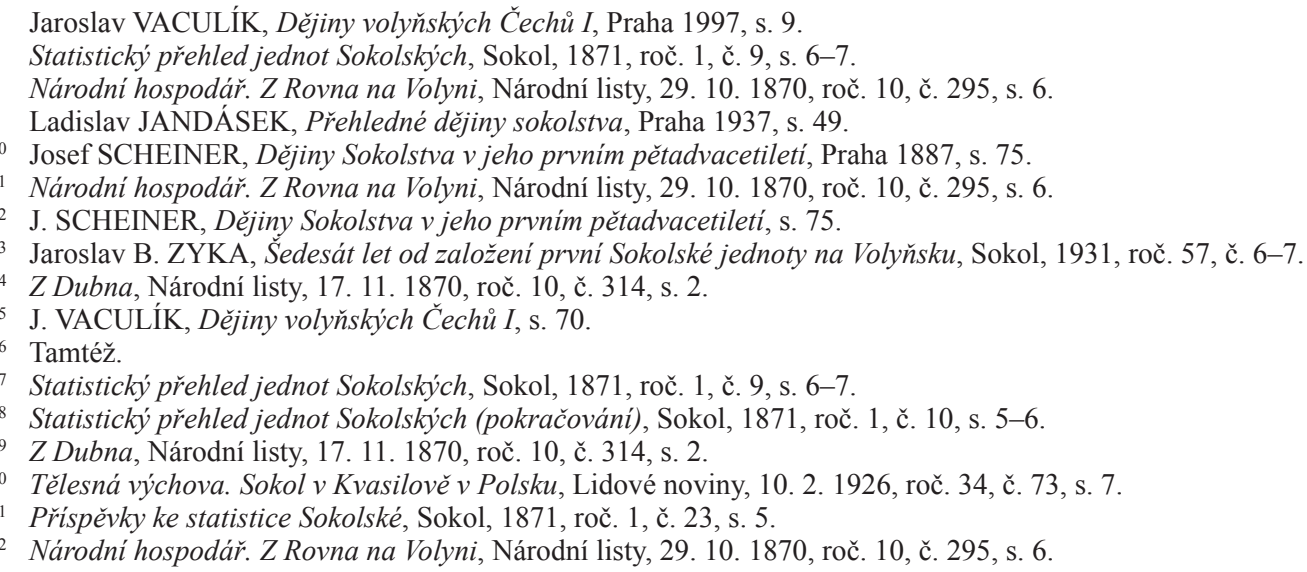


„Zde v Lucku zahájena slavnost v předvečer památného pro nás dne prưvodem s lampiony, jež nesli četní již Sokolové obce Teremno. "23 Informace o dalším působení sokolských jednot na Volyni v 19. století jsou prozatím nejasné a stejně tak podrobnosti jejich zániku - časopis Ruský Čech ho datoval do počátku 90. let v souvislosti se zánikem českých škol. ${ }^{24} \mathrm{Z}$ dostupných informací je pravděpodobné, že k tomu mohlo dojít již dříve, podle článku v pozdějším periodiku Sokol, kde jsou však i zřejmé některé faktické chyby, zanikly „záhy“" po vzniku. ${ }^{25}$

Další předválečný vývoj sokolstva ve volyn̆ské gubernii ovlivnila především první ruská revoluce, která opět změnila politickou konstelaci a pomáhala i rozvoji sokolských jednot. Snahy o rozkvět sokolského hnutí v Rusku podporovala také Česká obec sokolská, která již v srpnu roku 1905 uspořádala v Praze svoji první školu pro výchovu sokolských učitelů pro Rusko, kterou absolvovalo patnáct učitelů. ${ }^{26}$ Češi postupně získávali důležité postavení v nově vytvářených ruských sokolských jednotách např. v Petrohradu nebo Kamenci Podolském, kde byl náčelníkem nové jednoty Jindřich Vondra. ${ }^{27}$ Význam pro šíření sokolství v Rusku měla také česky psaná periodika Ruský Čech, Čechoslovan (pod redakcí V. Švihovského), či specializovaný časopis Sokolský list - ruský vydávaný českými učiteli tělocviku v Rusku (Vondráčkem, Olšaníkem a dalšími). ${ }^{28}$ Některé osobnosti z řad Čechů žijících v Rusku se účastnily větších sokolských akcí, naprríklad již všesokolského sletu v roce 1907 v Praze. Na následný šestý všesokolský slet, který byl zároveň prvním sletem nově vzniklého Svazu Slovanského sokolstva, přijelo v roce 1912 do Prahy z tehdejšího Ruska okolo 700 sokolů a zastoupena na něm byla většina tamních jednot z následujících měst - Astrachaň, Baku, Bohoduchov, Černihiv (Černigov), Charkov, Jekatěrinoslav (Dnipro), Jegorjevsk, Kaluga, Kamenec, Kyjev, Nižnij Novgorod, Moskva, Oděsa, Orel, Petrohrad, Poltava, Taganrog, Tiflis (Tbilisi), Tula, Voroněž, Vilna a Žitomír. ${ }^{29}$

Velký vliv pro budoucí vývoj na Volyni měla přeměna tělocvičného spolku Jih v Kyjevě díky povolení úr̆adů v gymnastický spolek Sokol, ${ }^{30} \mathrm{k}$ čemuž došlo okolo roku 1907. Spolek si rychle získával popularitu především mezi venkovským obyvatelstvem. ${ }^{31}$ Postupně v něm působil ve funkcích zapisovatele, místostarosty a posléze i starosty jeden z historicky nejvýznamnějších volyňských Čechů Václav Vondrák, který spolek zastupoval i ve Svazu ruského Sokolstva. ${ }^{32}$

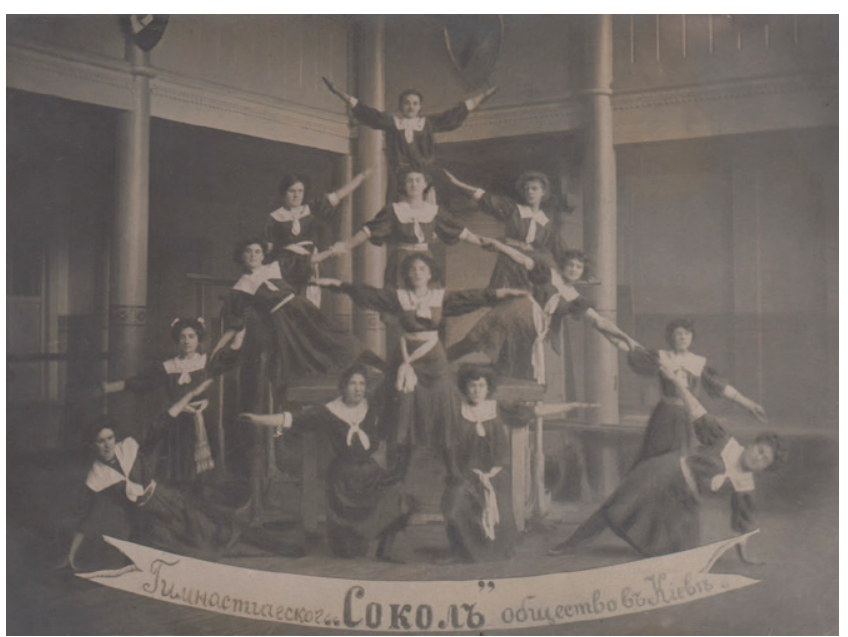

Obr. 1. Figurální cvičení žen gymnastického spolku Sokol v Kyjevě kolem roku 1911, Sbírka Národního muzea

Narůstání popularity kyjevského Sokola následně přineslo vznik Sokolů ve větších volyňských městech Dubně, Rovně a Žitomíru. ${ }^{33}$ Zásadní význam pro komunitu volyňských Čechů mělo rovněž založení sokolské jednoty $\mathrm{v}$ obci Kvasilov, $\mathrm{k}$ čemuž měla napomoct také návštěva dvou kvasilovských občanů na veřejném cvičení v Kyjevě. ${ }^{34}$ Dne 16. ledna 1911 byla jednota založena a následující rok pořádala první veřejné cvičení se zdařilým průběhem, ${ }^{35}$ $\mathrm{v}$ předválečném období čítala okolo 76 členů. ${ }^{36} \mathrm{~V}$ souvislosti $\mathrm{s}$ touto jednotou je nutno jmenovat především Antonína Perného, který byl zakladatelem i starostou jednoty a později v meziválečném období působil např́klad jako vydavatel asi nejvýznamnějšího českého periodika v oblasti s názvem Hlas Volyně, které často šírilo sokolské ideje ve svých článcích zejména v části časopisu s názvem „Sokolská hlídka“‘37 Jako náčelník jednoty zpočátku působil Josef Šorm a jako cvičitel Jaroslav Houška - bývalý člen Sokola v Plzni. Záhy byl jako cvičitel povolán na doporučení ČOS František Oliverious z Prahy, což následně napomohlo dalšímu rozkvětu jednoty. ${ }^{38}$ Činnost kvasilovského Sokola, který se ale také částečně potýkal s nepřízní ruských učitelů a jiných spolků, ${ }^{39}$ brzy načas přerušila první světová válka.

Také ve východnější části Volyně v žitomírském újezdu se začala sokolská organizace rozvíjet v letech nedlouho před vypuknutím první světové války. V Žitomíru byla podána žádost o registraci spolku Sokol dne 20. srpna 1910

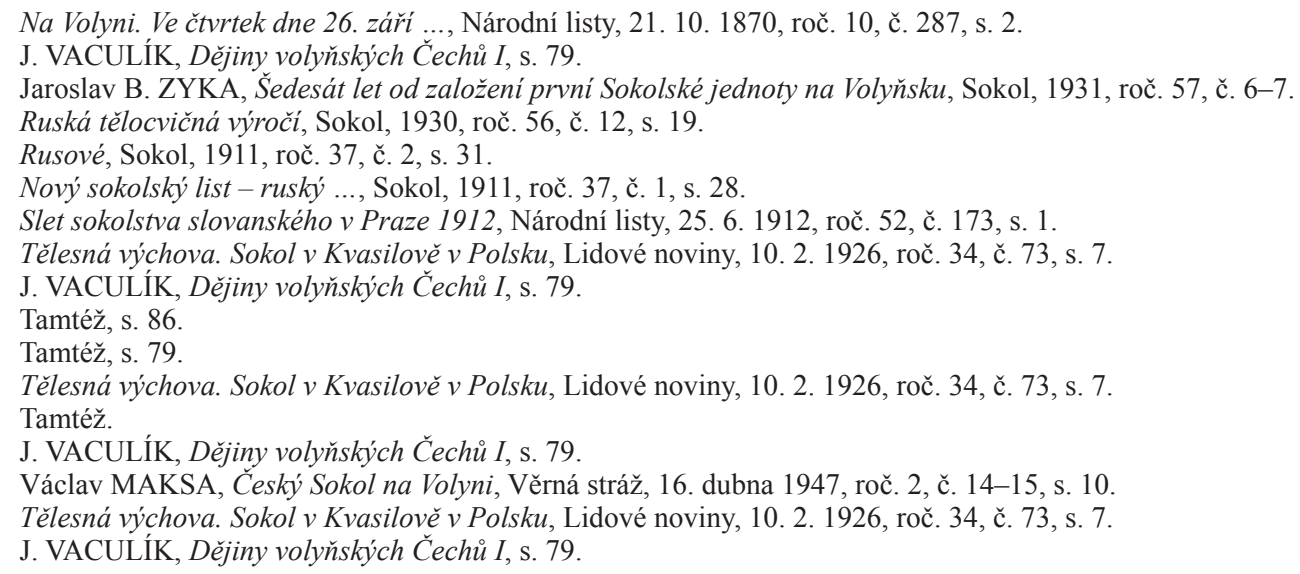


a již 2. září byla gubernátorem schválena. ${ }^{40}$ Do konce roku pak stoupl původní počet členů ze třiceti čtyř na padesát, z čehož bylo třináct žen. ${ }^{41}$ Stanovy tělocvičného spolku Sokol v Žitomíru měly ráz stanov župy, připouštěly tvoření sdružených spolků po celé Volyni. ${ }^{42}$ Historická mapa českého osídlení na Volyni uvádí, že v průběhu času působily ve východní části Volyně v žitomírském újezdu jednoty v následujících čtyřech obcích - Okolek, Olšanka, Vysoko České a Krošna Česká. ${ }^{43}$

Z obce Olšanka pocházel velkostatkár̆, vlastník pivovaru a jeden z největších pozemkových vlastníků mezi volyňskými Čechy Václav Klich, jehož nákladem bylo vydáváno periodikum Čechoslovan. Jeho syn Jaroslav Klich, narozený v roce 1898 , se více seznámil se sokolstvím zřejmě v Kyjevě, kde žil prribližně od svých čtrnácti let a cvičil v tamní jednotě. ${ }^{44}$ On i další mládežničtí členové kyjevského Sokola trávili letní prázdniny v Olšance, kde probíhalo každoroční letní cvičení v pivovarské zahradě. Tam byly instalovány kruhy, hrazda i bradla. Dětem se denně věnoval s velkým nadšením Jaroslav Klich spolu se svým starším bratrem Otakarem - cvičili s nimi, vyprávěli jim o zakladatelích Sokola a vysvětlovali význam sportu. Pokus o založení sokolské jednoty v Olšance však podle vzpomínek místního pamětníka ztroskotal, protože zde nebyl oficiální sokolský cvičitel. ${ }^{45}$

V obci Vysoko České existovala aktivní sokolská jednota pod vedením cvičitele Hrachovce, ${ }^{46}$ a stejně tak v obci Okolek sokolové nezůstávali se svou činností pozadu. Velká událost proběhla v Žitomíru dne 7. dubna 1914, kde v rámci bohatého programu vystoupili sokolové ze Žitomíru, Okolku i vesnice Vysoko České. I tato událost hojně reflektovaná v regionálních periodikách napomohla dalšímu rozrůstání členstva sokolstva $\mathrm{v}$ žitomírském újezdu a v předvečer první světové války bylo v sokolských spolcích v této oblasti činných již 169 mužů a 48 žen. ${ }^{47}$

\section{Vliv Sokola na dění 1. světové války}

Rozvoj sokolského hnutí na Volyni přerušila první světová válka. Té se zúčastnila řada volyňských mužů aktivních v Sokolech, do carské armády byli mobilizováni všichni muži s ruským občanstvím od 18 do 45 let, mezi nimi napríklad i starosta kvasilovské jednoty Antonín Perný. ${ }^{48} \mathrm{Ne}-$ odvedení muži se často hlásili do dobrovolnických oddílů České družiny. ${ }^{49} \mathrm{~V}$ tom hrály svou roli také ideály sokolství, které přivedly do České družiny i mnoho později významných důstojníků. ${ }^{50} \mathrm{~V}$ Dubně vstoupily do družiny více než dvě desítky mužů ${ }^{51}$ Také v Kvasilově se mobilizovala řada mužů z řad sokolů (mladší osmnácti let či s rakouským občanstvím), která tvořila důležitou část druhé roty: ${ }^{.2}$ „,Jakmile v srpnu r. 1914 došla zpráva, že tvořeni Družiny jest povoleno, tu kvasilovští sokolíci hned věděli, co mají dělat; osmnáct jich, kterých se mobilizace ještě netýkala, vyšli $v$ radách, za sokolských povelů, z rodné obce a za zpěvu sokolských písní nasedli ve Zdolbunově do vlaku, aby jeli do Kyjeva ". ${ }^{53}$ Po vypuknutí války se noví rekruti České družiny hlásili v kyjevské sokolovně, na čemž měl podíl i již zmíněný Václav Vondrák. ${ }^{54}$ Kyjevský Sokol také poskytoval českým a slovenským zajatcům možnost cvičení. ${ }^{55}$ Čeští sokolští cvičitelé na Rusi také často nahrazovali ruské důstojníky či poddůstojníky a starali se o vedení výcviků, kde kladli velký důraz na fyzickou připravenost. ${ }^{56}$

Někteří z volyňských sokolů během první světové války zemřeli, např́klad cvičitel kvasilovské jednoty František Oliverious, který byl raněný zajat rakousko-uherskou armádou a popraven. ${ }^{57}$ Již od roku 1937 je na jeho počest na náměstí v Radnicích v okresu Rokycany pamětní deska s tímto textem: ,, 7. XII. 1893 - 1. II. 1916, v tomto domě se narodil sokol - starodružiník František Oliverious, obětoval se při historické rozvědce prap. J. Syrového za svobodu milované vlasti “. ${ }^{58}$ Další Češi byli raněni (např. Alexandr Zach u Zborova) nebo museli prodělat sibiřskou anabázi jako Josef Malinský z kvasilovské sokolské jednoty. ${ }^{59}$

Obdobná situace byla v pozdější východní části Volyně v žitomírském újezdu, kde vstoupilo do armády 105 sokolư ${ }^{60}$ a velký zájem byl také o zapojení do České Družiny. Jen v Krošně České v předměstí Žitomíru do ní vstoupilo okolo dvou desítek mužů. ${ }^{61}$ Členové rodiny Klichů z Olšanky se aktivně účastnili bojů první světové války již od roku 1914,

\footnotetext{
40 Olexandr KUKHARSKIJ (O. С. Кухарський) - Grigorij GRIBAN (Г. П. Грибан), Istorija himnastychnoho tovarystva „, Sokil“ na Volyni, Žitomír 2015, s. 9.

41 O. KUKHARSKIJ - G. GRIBAN, Istorija himnastychnoho tovarystva ,, Sokil“ na Volyni, s. 10.

42 Tělesná výchova. Sokol v Kvasilově v Polsku, Lidové noviny, 10. 2. 1926, roč. 34, č. 73, s. 7.

43 Jaroslav KLICPERA - Věra PELCOVÁ - Jiří HOFMAN, Historická mapa českého osídleni na Volyni, Praha 1995, s. 8-22.

44 Alexandr MURATOV - Dina MURATOVÁ, Deset mužů z rodiny Klichư v České Družině, Zpravodaj Sdružení Čechů z Volyně, 2015 , č. 4.

45 Národní muzeum, H8-b. č., anketní popis volyňských obcí, Olšanka.

46 Národní muzeum, H8-b. č., anketní popis volyňských obcí, Vysoko České.

47 O. KUKHARSKIJ - G. GRIBAN, Istorija himnastychnoho tovarystva ,, Sokil “ na Volyni, s. 26.

48 Popis české obce Kvasilov na Volyni, Věrná Stráž, 1949, roč. 4, č. 5-6.

49 J. VACULÍK, Dějiny volyňských Čechů II, s. 9.

50 Dalibor VÁCHA, Život v legiích. Českoslovenští dobrovolci na Rusi 1914-1918, disertační práce, Jihočeská univerzita v Českých Budějovicích, 2011, s. 44.

51 J. VACULÍK, Dějiny volyňských Čechů II, s. 10.

52 Tamtéž, s. 9.

53 Josef NÁHLOVSKÝ, Kronika obce Kvasilova, Kvasilov 1929, s. 33.

54 J. VACULÍK, Dějiny volyňských Čechů II, s. 9.

55 Dagmar MARTINKOVẢ, Podíl ruských Čechů na československém odboji na počátku velké války, Sborník prací Masarykovy univerzity, řada společenských věd, Brno 2015, s. 22.

56 D. VÁCHA, Život v legiích, s. 52.

57 Mikuláš ŠEREŤUK, Kronika Českého Kvasilova, 2003, s. 21.

58 Dostupné online na stránkách Spolku pro vojenská a pietní místa: https://www.vets.cz/vpm/5887-pametni-deska-frantisek-oliverius/

59 Josef NÁHLOVSKÝ, Kronika obce Kvasilova, Kvasilov 1929, s. 34.

60 O. KUKHARSKIJ, G. GRIBAN, Istorija himnastychnoho tovarystva , Sokil“ na Volyni, s. 26.

61 J. VACULÍK, Dějiny volyňských Čechü II, s. 10.
} 


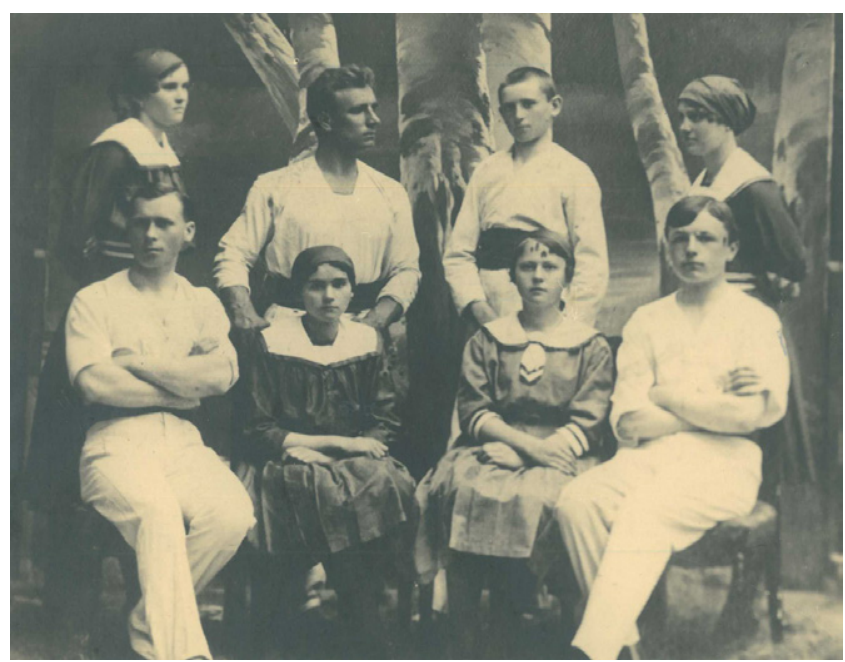

Obr. 2. Sokolové z Krošny České se cvičitelem Tomanem (stojící druhý zleva), Sbírka Národního muzea

mimo jiné i ve čtvrté rotě. Ta byla během roku 1916 převelena z rozkazu štábu do Kamence Podolského, kde byla ve velkém sále organizována sokolská představení a ruští vojáci i důstojníci se na ně chodili dívat, ${ }^{62}$ obdobná cvičení za války v armádě však nebyla výjimkou. V žitomírském újezdu pokračovala sokolská činnost nejpozději od roku 1917, kromě obcí Okolek a Vysoko České začala jednota působit také v Krošně České, kde cvičili žáci, muži i ženy. Jako cvičitel zde působil Štěpán Toman, který se nedlouho předtím vrátil z války. ${ }^{63}$

\section{Sokolské jednoty v meziválečném období na západní Volyni}

Události spojené s první světovou válkou přinesly velké množství územních změn, které se bezprostředně dotkly i oblasti Volyně. Překotný vývoj za první světové a ruské občanské války se načas ustálil po podepsání polsko-ruské mírové smlouvy, k čemuž došlo v březnu 1921 v Rize. Touto dohodou byla západní část volyňské gubernie přičleněna $\mathrm{k}$ Polské republice. V této části Volyně žila i početná komunita emigrantů z českých zemí, konkrétně 30977 lidí dle mateřského jazyka. ${ }^{64} \mathrm{O}$ něco menší část území na východě s více než sedmi tisíci volyňskými Čechy připadla Ukrajinské sovětské socialistické republice.

Právě politická správa byla rozhodujícím faktorem v možnosti působení sokolských jednot na Volyni. České jednoty v západní Volyni se mnohdy potýkaly s polskými státními orgány, částečně kvưli vzájemným diplomatickým sporům mezi oběma státy, a určitou roli pak hrála i působnost Svazu polského sokolstva v oblasti. Už během roku 1924 v něm v rámci jedenáctého (volyňského) okresu působily jednoty zejména ve větších obcích, jednalo se o Kremenec, Kvasilov, Luck, Rovno, Volodymyr-Volynskyj a Zdolbunov. Následně se k nim přidaly ještě jednoty v následujících místech: Dąbrowica, Kovel, Korec, Rožyšče, Olyka, Tsuman a Wólka Kotowská. ${ }^{65}$ Také v Dubně působil podle straklovské kroniky polský Sokol, ${ }^{66}$ zřejmě tím byla myšlena také jednota působící v rámci Svazu polského sokolstva.

Potíže s polskou vládou při obnovování sokolských jednot a zakládání nových neřešili pouze Češi, ale také Ukrajinci žijící v oblastech přičleněných rižským mírem k Polsku. To lze ukázat na př́kladu ukrajinského Sokola Bat'ko ve Lvově, jemuž byl při policejní razii v roce 1923 dokonce zabaven sokolský prapor. ${ }^{67}$ Obdobné problémy řešily i české jednoty v západní části Volyně. K obnovení činnosti kvasilovské jednoty po první světové válce došlo v roce 1922, na doporučení ČOS byli opět na Volyň vysláni cvičitelé z Čech - Jan Šebek z Vejprnic u Plzně a František Petlach z Kanic na Moravě, protože zároveň vznikly na Volyni sokolské jednoty také v obcích Volkov, Mirohošt', Zdolbunov a pomýšlelo se na utvoření samostatného českého okrsku. ${ }^{68}$ Zejména kvưli vlivu vysokého úředníka $\mathrm{v}$ Lucku předsedy okruhu Jaworowského došlo k zániku všech českých sokolských jednot vyjma kvasilovské, a ačkoliv ještě rok 1923 pro ni znamenal velký rozkvět (měla okolo 150 členů, vlastní kapelu a zúčastnila se sletu polského sokolstva), ${ }^{69}$ tak se museli také činovníci z Kvasilova vyrovnávat s komplikacemi ze strany polských úřadů. ${ }^{70}$

Věstnik sokolský k tomu v roce 1924 uváděl: ,, Sokolstvu českému v Kvasilově nechtěji príslušné úřady povolit stanovy z toho di̊vodu, že hlásí se (sic) dobrovolně do Svazu Sokolstva polského, ale hrüzo!, chce udržovat bratrské styky s bratrským Svazem Sokolstva v Československu. A naléhají, aby tato věta ze stanov byla škrtnuta, hrozíce jinak nepovolením. "71 Kvasilovský Sokol se snažil vymoci si možnost používat české povely, mít češtinu jako jednací řeč nebo nosit český sokolský kroj. ${ }^{72}$ Tyto parametry patřily k hlavním rozdílům v praktickém fungování sokolských jednot $\mathrm{v}$ rámci Svazu polského sokolstva a Československé obce sokolské. Nastalá situace tak kvasilovský Sokol paralyzovala, někteří jeho činovníci svoji působnost ve spolku kvůli sporům ukončili, z Volyně odjel v roce 1923 zpět do Československa cvičitel Šebek a v roce 1925 také cvičitel Petlach, kterému jeho zaměstnání nestačilo na živobytí. ${ }^{73}$ Během jeho působení na Volyni se mu podařilo ustavit cvičitelský sbor, ${ }^{74}$

62 Alexandr MURATOV - Dina MURATOVÁ, Deset mužů z rodiny Klichů v České Družině, Zpravodaj Sdružení Čechů z Volyně, 2014 , č. 9.

63 O. KUKHARSKIJ, G. GRIBAN, Istorija himnastychnoho tovarystva ,, Sokil“" na Volyni, s. 27-29.

64 J. VACULÍK, Dějiny volyňských Čechủ II, s. 24.

65 Teresa Drozek-MEŁOLEPSZA - Eligiusz MEŁOLEPSZY, Z dziejów Towarzystwa Gimnastycznego „Sokót” okręgu wolyńskiego (1922-1939), in: PRACE NAUKOWE Akademii im. Jana Dlugosza w Częstochowie, Czestechowia 2018, s. 73-81.

66 Alexandr KŘIVKA, Kronika sokolské tělocvičné jednoty ve Straklově Českém. Straklov, 1935, s. 3.

67 Ukrajinský Sokol v Haliči, Věstník Sokolský, 1924, roč. 26, č. 32.

68 Télesná výchova. Sokol v Kvasilově v Polsku, Lidové noviny, 10. 2. 1926, roč. 34, č. 73, s. 7.

69 Tamtéž.

70 Tamtéž

1 Drobnosti. O slovanském citěni polských úradů, Věstník Sokolský, 1924, roč. 26, č. 32

72 Tělesná výchova. Sokol v Kvasilově v Polsku, Lidové noviny, 10. 2. 1926, roč. 34, č. 73, s. 7.

73 Tamtéź.

74 J. VACULÍK, Dějiny volyňských Čechi̊ II, s. 29. 


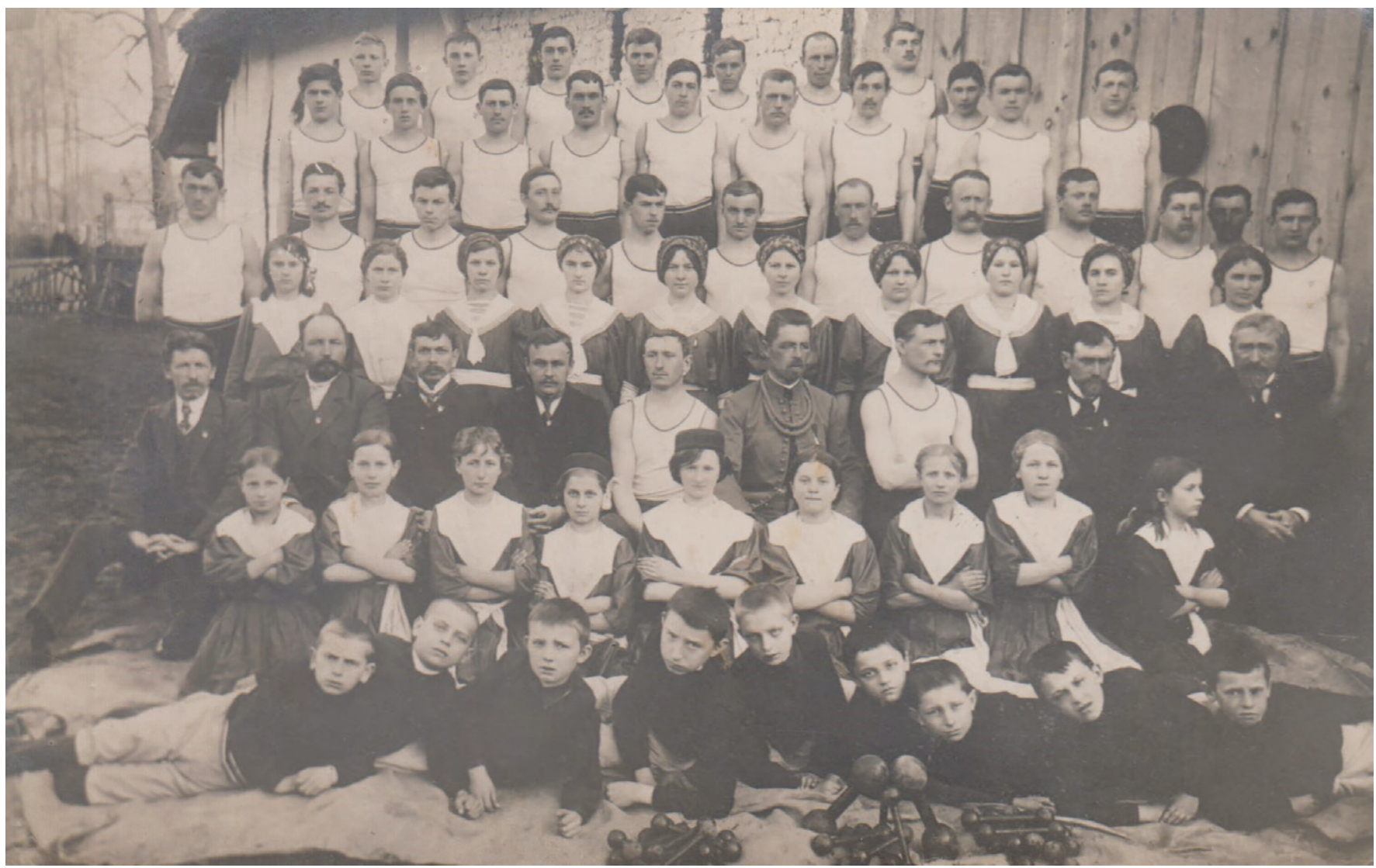

Obr. 3. Skupinová památeční fotografie části sokolů z Kvasilova z roku 1923, Sbírka Národního muzea

později se na Volyň vrátil a vykonával činnost sokolského okrskového vzdělavatele. ${ }^{75}$

Kvasilovská jednota toto krizové období úspěšně překonala a každoročně $\mathrm{i}$ během něho pořádala veřejná cvičení a tělocvičné besídky. ${ }^{76} \mathrm{~V}$ roce 1926 přijela pětičlenná delegace z této jednoty pomoci založit také další sokolskou jednotu v obci Český Straklov a seznámit místní se sokolskou myšlenkou. Ustavující schůzka však byla v jejím průběhu ukončena polským policistou, připravované stanovy odebrány a dva z iniciátorů schůzky obdrželi pokutu ve výši 20 zlotých. ${ }^{77}$ Během 20 . let se Čechům v oblasti tak podařilo založit již pouze jednotu ve Zdolbunově, potvrzenou úř́ady dne 9. srpna 1927, ve které byla dlouholetým starostou místní výrazná osobnost Alexandr Khol. ${ }^{78} \mathrm{~K}$ založení Sokola ve Strakově finálně došlo po dalších problémech s polskými úřady až o pět let později. K legalizování jednoty bylo nutno zaslat stanovy k potvrzení do oblastního města Luck. V př́ipadě Českého Straklova se vrátily nepotvrzené a k jejich podepsání došlo až následující rok po urgenci jediného zástupce v polském sejmu z řad volyňských Čechů Vladimíra Meduny, za což se mu dostalo poděkování i v krajanském tisku. ${ }^{79}$

Informace o přesném letopočtu založení sokolských jednot se vzhledem $\mathrm{k}$ tomu, že jednoty mnohdy působily už před oficiálním schválením úřady, a $\mathrm{v}$ závislosti na zdroji informací liší. Názorným př́íkladem může být také obnovená sokolská jednota v obci Mirohošt'. Podle vzpomínek místního rodáka došlo k opětovnému obnovení její činnosti již v roce $1928 .{ }^{80}$ Jaroslav Vaculík ve své knize uvádí rok 1929, periodikum Sokol či sokolská kronika Straklova pak až letopočet 1930, který zřejmě odpovídá realitě. V průběhu času došlo např́iklad také k chybnému vzpomínání na datum původního založení mirohošt'ské jednoty, namísto roku 1870 periodikum Sokol uvádělo datum 1871, kdy mělo dojít k založení jednoty v rámci valné hromady Sokolů volyňských v den ,slovanských apoštolů Cyrila a Metoděje“ dne 11. května. ${ }^{81}$

Díky postupnému zlepšení poměrů mezi Československem a Polskem mohla v létě roku 1930 přijet na Volyň na přání místních volyňských Čechů prostřednictvím ČOS skupina sokolů, která zde navštívila české jednoty včetně nově vytvořených v Mirohošti a Rovně. Také navštívila Českou Huleč, kde se založení sokolské jednoty připravovalo. Podle straklovské kroniky se jednalo o závodní družstvo zahraniční župy, ${ }^{82}$ podrobnější novinové zprávy píší, že na Volyň byla zahraniční župou vyslána dvě družstva jednoty zlínské z župy Hanácké, přičemž finanční podporu na tento zájezd

75 Alexandr KŘIVKA, Kronika sokolské tělocvičné jednoty ve Straklově Českém, Straklov 1935, s. 7.

76 Tělesná výchova. Sokol v Kvasilově v Polsku, Lidové noviny, 10. 2. 1926, roč. 34, č. 73, s. 7.

77 A. KřIVKA, Kronika sokolské tělocvičné jednoty ve Straklově Českém, s. 2.

78 Miroslav KRUŠINA, Zdolbunov - mésto na Ukrajinské Volyni ve vzpomínkách české minority, Otradovice 2009 , s. 87 a s. 135.

79 A. KŘIVKA, Kronika sokolské tělocvičné jednoty ve Straklově Českém, s. 2-3.

80 Národní muzeum, H8-b. č., anketní popis volyňských obcí, Mirohošt' Česká.

81 J. B. ZYKA, Šedesát let od založení první Sokolské jednoty na Volyňsku, Sokol, 1931, roč. 57, č. 6-7.

82 A. Kर̌IVKA, Kronika sokolské tělocvičné jednoty ve Straklově Českém, s. 2. 


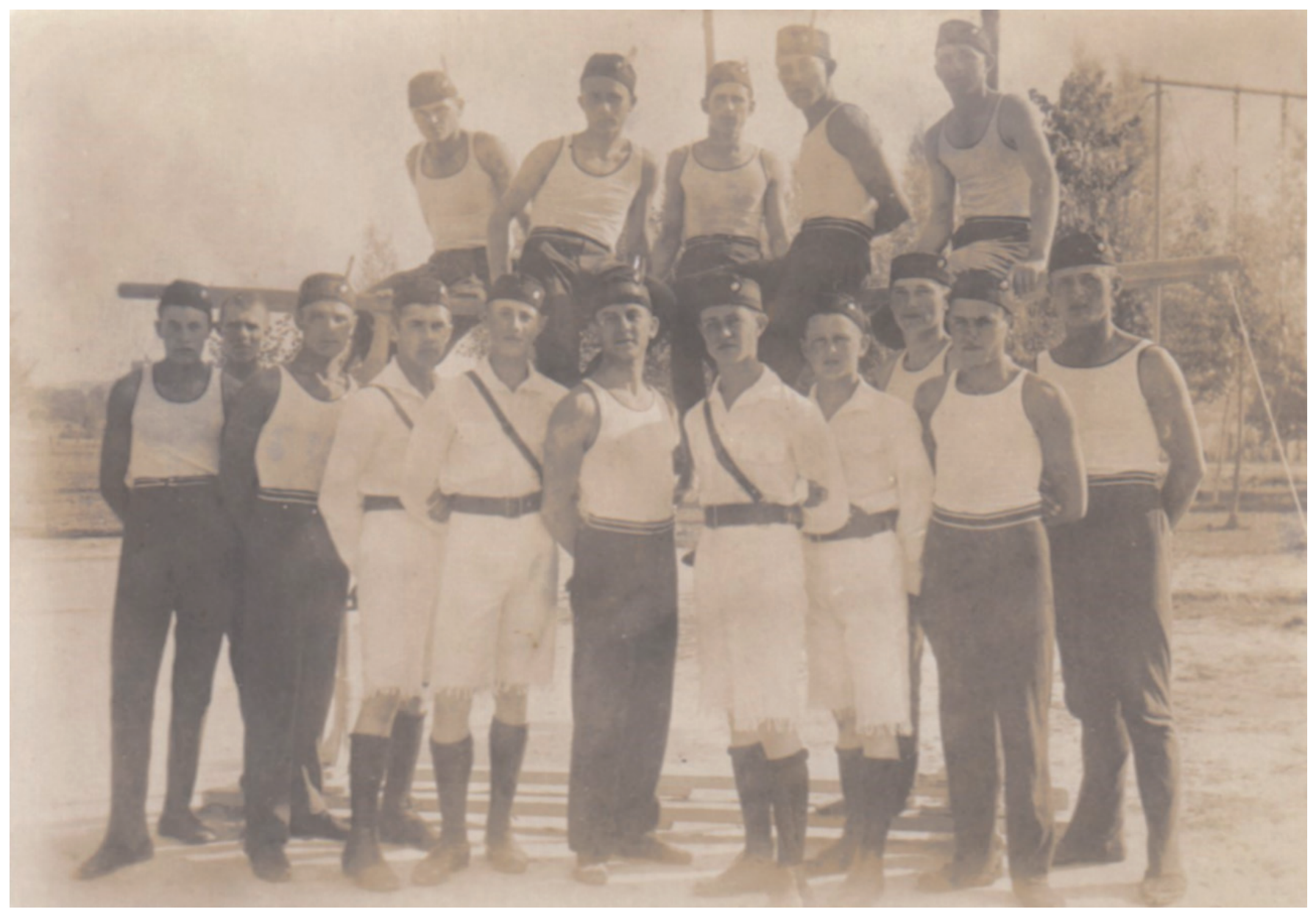

Obr. 4. Fotografie členů obnoveného Sokola v Mirohošti okolo roku 1931, Sbírka Národního muzea

poskytl např. zlínský podnikatel Bat’a. Během desetidenního zájezdu navštívila výprava všechny tou dobou fungující jednoty (Kvasilov, Zdolbunov, Mirohošt', Rovno) a účastnila se zde sokolských akademií i veřejných cvičení. ${ }^{83}$

O zájezdu referoval Věstník sokolský takto: ,Zájezd vůbec vykonal veliký kus práce na poli kulturního povznesení české větve volyňské. Na četných mistech výprava byla vitána zástupci polských jednot sokolských a žup [...], zástupci úřadi̊ a ústavi̊ [...] a tak mimoděk se stala významným činitelem v česko-polském sbližení. Přijetí našimi krajany na všech mistech, kde alespoň hrstka našinců žije, bylo tak jedinečné a dojemné, že zůstane vzpomínka na ty krásné chvíle trvalou v dušich všech účastníkü “. ${ }^{84}$

Tato návštěva měla velice pozitivní efekt, probudila touhu i v dalších vesnicích po založení Sokola. Počátek 30. let lze považovat za vrchol zakladatelské horečky sokolských jednot Čechů v západní části oblasti. Volyňské jednoty se postupně stávaly nejpočetnější složkou zahraniční župy ČOS a v roce 1930 došlo i k ustavení druhého (tj. volyn̆ského) okrsku v rámci ní, ${ }^{85}$ jako okrskový náčelník působil během 30. let Martínek. ${ }^{86}$
Přesto se stále v polské Volyni i v první polovině 30. let našli činitelé potlačující českou sokolskou činnost. Jako příklad lze zmínit učitele Ignacy Bielawského z obce Česká Huleč, který se dle knihy o obci vyznačoval „,národnostní nesnášenlivostí", zakazoval dětem o přestávkách mluvit česky či ukrajinsky s př́ípadnými tělesnými postihy a zakazoval jim zpravidla neúspěšně taktéž chodit do místního Sokola po jeho založení v roce $1930 .{ }^{87}$ Tento případ byl v tomto období již ale spíše výjimkou.

Jako starosta kvasilovského Sokola začal okolo roku 1923 působit místní významný podnikatel inženýr Vladimír Svárovský, pozdější generální konzul na Volyni. ${ }^{88}$ I jeho osobnost zřejmě napomáhala dobrým vztahům s polskými vládními činiteli, např. před všesokolským sletem v roce 1932 byly jeho prostřednictvím vyrobeny speciální štítky se znakem ČOS Kvasilov pro polského prezidenta Moścického, maršálka Józefa Piłsudského a starostu Svazu polského sokolstva Adama Zamoyského. ${ }^{89} \mathrm{O}$ postupné změně postojů svědčí např́iklad první velké závody českých jednot na Volyni v roce 1933. Ty se podle zprávy župního náčelníka Pláničky konaly za účasti zástupců polských úřadů, mezi tisíci

83 Zájezd župy Zahraniční k českým sokolským jednotám na Volyň, Věstník Sokolský, 11. 9. 1930, roč. 32 , č. 35.

84 Tamtéž

85 J. VACULÍK, Dějiny volyňských Čechů II, s. 30.

86 Čilý sokolský ruch na Volyňsku, Věstník Sokolský, 1934, roč. 36, č. 8.

87 Jiř́ BONEK - Danuše MANOVÁ - Václav STÁREK, Huleč Česká na Volyni, Žatec 1992, s. 135.

88 J. VACULÍK, Dějiny volyňských Čechů II, s. 47.

89 M. ŠEREŤUK, Kronika Českého Kvasilova, s. 22. 


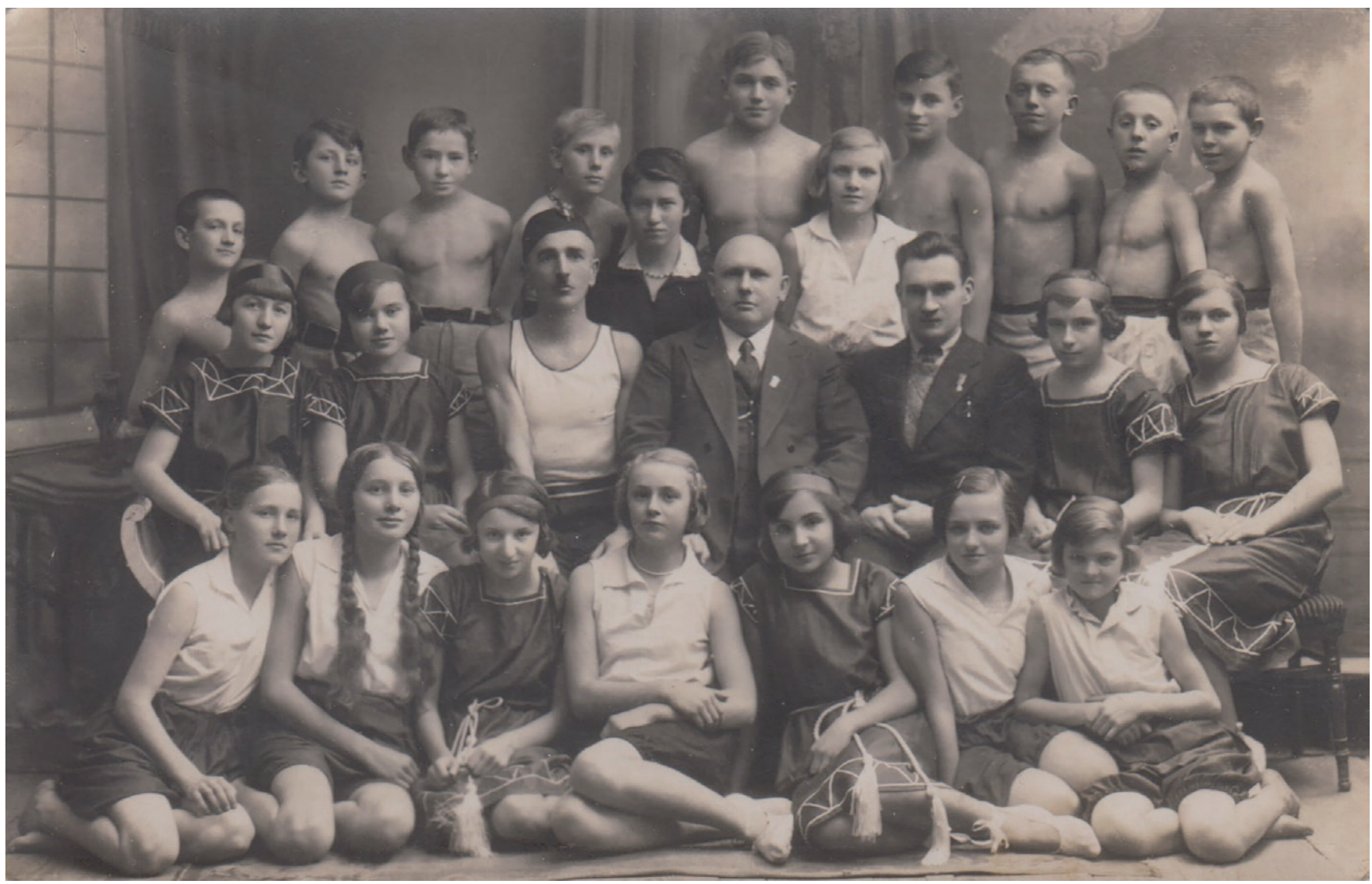

Obr. 5. Zejména mladí členové Sokola Rovno s náčelníkem jednoty Maksou v roce 1933, Sbírka Národního muzea

návštěvníky bylo mnoho Poláků a Ukrajinců, kromě polské hymny zde zahrála i hymna československá a proslovy s přípitky se děly ve znamení ,českopolského bratrstvi““ 90 Župní náčelník oceňoval loajalitu Čechů k ,přátelskému Polsku“ a věrnost slovanské vzájemnosti. ${ }^{91}$ Tato zpráva tak obsahuje jednu z mála zmínek v dobových zdrojích o zájmu mnohých ukrajinských či polských obyvatel Volyně o české sokolské jednoty.

Ve druhé polovině 30. let se opět situace měnila zejména kvůli přístupu polských úřadů a silně protičeskoslovenské politice ministra zahraničí Józefa Becka a vyústila v další útlak volyňských Čechů: ,, Tak ve městech, když rádily nejvíce štvanice proti Čechưm, čeští chlapci, príslušníci Sokola, pripinali si na klopy svých kabátů sokolské odznaky a na místech nejvice frekventovaných demonstrativně vedli hlučné rozmluvy ve své mateřštině “. ${ }^{92}$ Další české sokolské jednoty na Volyni dále již nepřibývaly, naopak v Dubně a Semidubech okolo let 1936-37 zanikly. ${ }^{93}$ Situace vyústila v problémy s povolováním veřejných cvičení a v roce 1938 nebyly povoleny polskými úřady každoroční závody českých volyňských jednot.

Celkový počet sokolských jednot $\mathrm{v}$ západní Volyni se v různých zdrojích informací zásadním způsobem liší. Většina prací o Češích z Volyně uvádí počet dvaceti čtyř jednot, který je získaný původně z Historické mapy českého osídlení na Volyni a s velkou pravděpodobností neodpovídá dobové realitě. Jejich počet byl zřejmě přibližně jen poloviční. Okrskový náčelník Jaroslav Perný odhadoval, že všech dvanáct volyňských jednot čítalo asi 2700 cvičících a 1500 přispívajících členů. Tento počet se $\mathrm{z}$ dostupných pramenů zdá jako nadsazený, stejně jako některé z dalších jeho uváděných čísel. ${ }^{94}$ Podle nahlášených údajů do ročenky zahraniční župy byl stav členstva $\mathrm{v}$ jednotlivých jednotách $\mathrm{v}$ roce 1933 následující (muži/ženy): Dubno (17/9), Huleč (16/10), Hlinsk (20/12), Kvasilov (34/13), Mirohošt' (31/22), Moldava I + Moldava II (28/9), Rovno (27/12), Straklov (12/1), Semiduby (12/1), Volkov (22/8) a Zdolbunov (29/6). ${ }^{95}$ Podle těchto údajů ve všech jednotách výrazně převládal počet mužů (dohromady 248) oproti ženám (dohromady 103). Velkou část členstva sokolských jednot tvořila mládež, tj. dorostenci/dorostenky a především žáci/žačky. Počet aktivních členů a zejména členek v jednotách se v průběhu času turbulentně měnil, roli v tom hrály například i přibližující se okrskové závody, veřejné cvičení či všesokolský slet v Praze. Před nimi zpravidla účast na sokolských akcích značně stoupala, po jejich uskutečnění naopak mnohdy postupně ochota účastnit se akcí klesala.

90 J. PLÁNIČKA, Slavnosti volyňského sokolstva, Věstník Sokolský, 24. 8. 1933, roč. 35, č. 32.

91 J. PLÁNIČKA, Sokolská činnost za hranicemi, Věstník Sokolský, 1933, roč. 35, č. 24.

92 Josef V. REJZEK, Nezradili. Generační obraz volyňských Čechů, Brno 1947, s. 52.

93 Zahraniční sokolstvo, Lidové noviny, 30. 4. 1937, roč. 45, č. 218 , s. 5.

94 M. ŠEREŤUK, Kronika Českého Kvasilova, s. 22.

95 Národní muzeum, H8-24083, Sokolská župa zahraniční, 1933. 


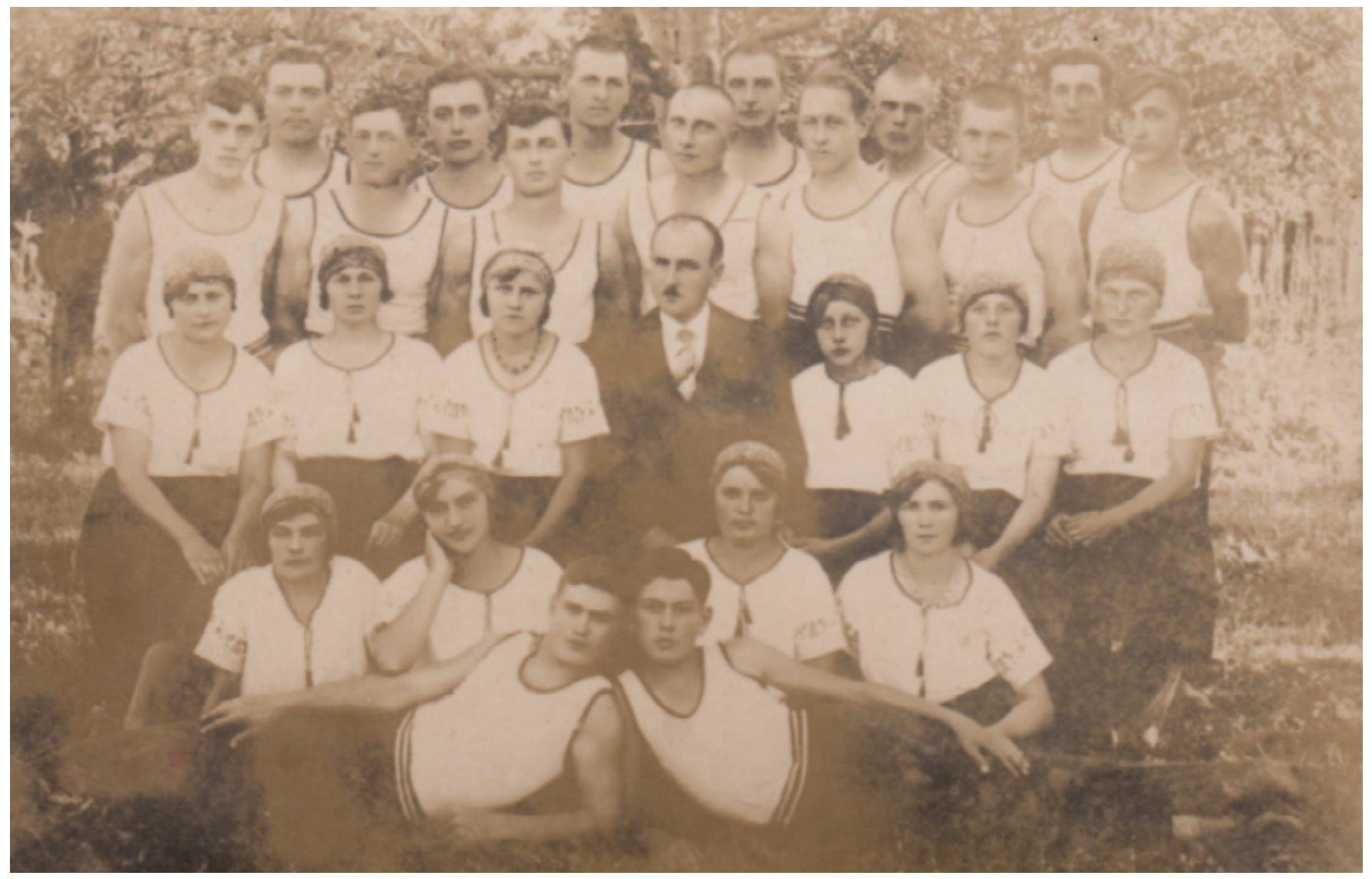

Obr. 6. Sokolská jednota v Semidubech se starostou jednoty učitelem Fickem, Sbírka Národního muzea

Ačkoliv je Historická mapa českého osidlení na Volyni unikátním zdrojem jinak neznámých informací, tak vzhledem ke způsobu vzniku, tj. až v 90. letech 20. století anketními otázkami položenými volyňským reemigrantům, obsahuje řadu nepřesností. V ní jsou uvedeny sokolské jednoty také v obcích Boratín, Curkov, Dlouhé Pole, Kopče, Ledochovka, Mstěšín - Ládovka, Nový Svět, Omelanština, Podcurkov, Sedmihrany, Zálesí a Zikmundovka. V obci Niva Hubínská sice není uvedena sokolská jednota, ale údajně zde stála dokonce Sokolovna. ${ }^{96}$ Zmínka o snaze vytvořit nový Sokol v obci Zálesí lze dohledat ve Věstníku sokolském v roce $1933^{97}$ a podle pozdějších informací spadalo Zálesí pod Českou Huleč. ${ }^{98}$ Snaha o nalezení informací o působnosti dalších jednot dopadla neúspěšně. S velkou pravděpodobností a přihlédnutím i k tomu, že žádné z nich nejsou zmíněny ani v detailní kronice straklovské sokolské obce, lze soudit, že minimálně ve většině těchto obcí neexistovaly schválené sokolské jednoty. To však v některých př́padech neznamenalo, že sokolské aktivity neovlivňovaly životy řady jejich občanů, kteří například mohli být členy Sokolů v jiných obcích. Popis jedné $\mathrm{z}$ fotografií ve sbírkách Národního muzea svědčí o tom, že obyvatelé obce Dlouhé Pole byli členy sokolské jednoty v přibližně dva kilometry vzdálené obci Semiduby. Jako další př́iklad poslouží Český Boratín, v něm místní učitelé Vlk a Svoboda organizovali a nacvičovali sokolská cvičení a mládež se zde připravovala i na účast na Všesokolském sletu v Praze, ${ }^{99}$ ale oficiální sokolská jednota zde s velkou pravděpodobností založena nebyla. V dobových periodikách je naopak několikrát zmíněn počátek snah o založení českých sokolských jednot v dalších obcích, např. Ulbárově ${ }^{100}$ či Lucku, kde úspěšně fungoval již polský Sokol. Zřejmě na jeho založení se podílel další významný volyňský Čech Václav Mesner, který působil jako hasičský náčelník pro celou oblast Volyně. Členům Sokola z Lucku umožnil cvičit $\mathrm{v}$ prostorách hasičského sboru na zámku knížete Lubarta. ${ }^{101}$

\section{Materiální vybavení českých sokolských jednot na západní Volyni}

Ve většině vesnic na Volyni s působností českého Sokola se cvičilo v upravených venkovních prostorech nebo v multifunkčních sálech původně nesouvisejících se sokolstvím, v několika obcích byly postaveny tělocvičny až po delší době působení jednoty v dané obci během 30. let. Žrejmě jednu z prvních větších sokolských budov postavili občané

96 J. KLICPERA - V. PELCOVÁ - J. HOFMAN, Historická mapa českého osídlení na Volyni, Praha 1995, s. 8-22.

97 J. PLÁNIČKA, Slavnosti volyňského sokolstva, Věstník Sokolský, 24. 8. 1933, roč. 35, č. 32.

98 Dostupné online: https://www.volynaci.cz/file/1153/557-Rovno-Kravilov-Hulec-Klinsk-A-DALSI-Viktor-Simek-anketni-listek. pdf?fbclid=IwAR2pV6527sWjJBk2KQLlttfCUCNA3fA18rnZjpNpFTvYVB MTIYG7TB2fk

99 J. VLK - A. VLKOVÁ - V. VLK; Historie Českého Boratína, Ústí nad Labem 2000, s. 63-112.

100 O nás, Věstník Sokolský, 13. 7. 1933, roč. 35, č. 28.

101 Markéta KUBOVÁ, Kultura a školství volyňských Čechů ve 20.-30. letech 20. století, bakalářská práce, Univerzita Hradec Králové, 2015 , s. 50. 


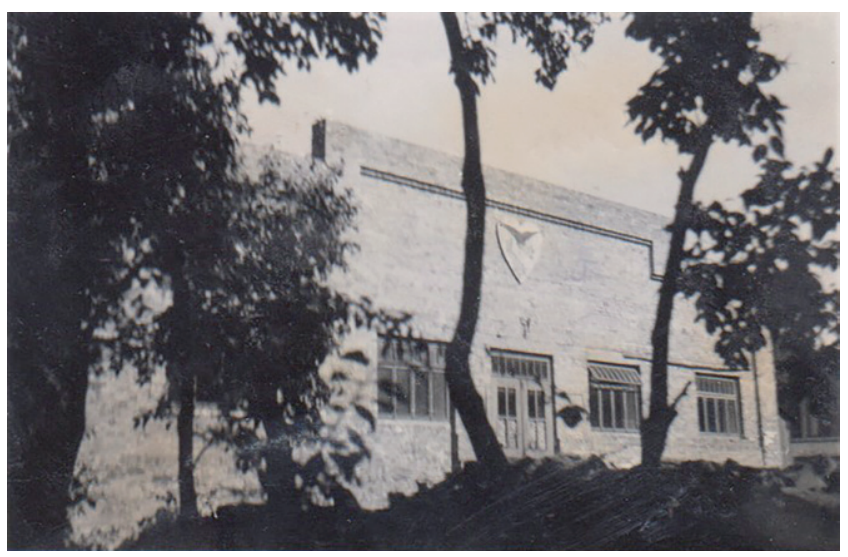

Obr. 7. Budova kvasilovské sokolovny za stromy, Sbírka Národního muzea

Mirohoště po opětovném založení jednoty a slavnostně ji otevřeli v rámci závodů v roce 1933. „Majetní bratři dali ze svých nemovitostí kámen, písek, dřevo, povozy, vápno a všichni pak radostně stavěli“ ${ }^{102}$ Sokolovna měla rozměry 22x16 metrů (kromě dvou velkých ochozů), jeviště 10x9 metrů a byla vysoká sedm metrů. ${ }^{103} \mathrm{~V}$ Kvasilově se dlouho cvičilo $\mathrm{v}$ létě ve venkovních prostorech a $\mathrm{v}$ zimě ve zděném, klenutém a vymalovaném chlévě, který byl však tmavý a pro jednotu neměl dostatečnou kapacitu. Navíc byl načas tento prostor zabrán vojenskou jednotkou (pohraniční stráží), což negativně působilo na chod sokolské jednoty. ${ }^{104}$ Dlouhodobá nutnost postavit v obci novou sokolovnu, která se stala střediskem kulturního života $\mathrm{v}$ obci, byla naplněna až ve 30. letech. Nářadí používané v Kvasilově ke cvičení již před první světovou válkou bylo používáno i v období meziválečném. ${ }^{105}$

Nelehké podmínky po založení jednoty dokládá situace ve Zdolbunově, kde se cvičilo v soukromých bytech a za př́padné cvičení $\mathrm{v}$ sále bylo nutno zaplatit 17 zlotých, ${ }^{106}$ později byla zřejmě i zde postavena tělocvična. ${ }^{107} \mathrm{~V}$ Moldavě I zpočátku nebylo žádné tělocvičné nářadí, což způsobovalo nutnost zhotovovat si provizorní. Místo sloupů na kruhy se používaly sloupy z chmelnice, na ulici se postavila provizorní bradla a hrazda. Postupně se $\mathrm{z}$ výtěžků ze zábav a darů pořizovalo originální nářadí. Letní cvičiště pro sokoly bylo vytvořeno $\mathrm{v}$ zahradě u školy, kde se srovnalo pole a navezl na něj písek. V roce 1935 postavil místní občan Kostka sokolský sál, kde v zimě kromě sokolských cvičení probíhala i divadelní představení. ${ }^{108}$ Naopak např́klad v Českém Straklově bylo tělocvičné nářadí objednáno ihned po založení jednoty u pana Svárovského. Zakoupeny byly i stejnokroje. V této obci se používal sál (Sokolovna) majitele Vladímíra Veselého, který byl sám přispívajícím členem jednoty, ale v roce 1937 zemřel. Následně řešenou stavbu Národního domu v obci na pozemku starosty Srba zřejmě zastavily dobové okolnosti. ${ }^{109} \mathrm{~V}$ Hlinsku se zpočátku cvičilo na venkovním cvičišti na „Hoře“ a místní sokolové si zde díky své píli vybudovali i malý stadion. ${ }^{110}$ Ve Volkově jednota cvičila ve velkém sále, který stál na návsi, a bylo $\mathrm{v}$ něm $\mathrm{k}$ dispozici veškeré potřebné cvičební nářadí. $\mathrm{V}$ létě v něm byl př́ijemný chlad, v zimě se vytápěl velkými kamny. Během léta se za příznivého počasí cvičilo také na zahradě místního občana Vladimíra Fořta, který ji dovolil předělat na sokolské cvičiště. ${ }^{11}$ Sokolská jednota z obce Huleč využívala velký multifunkční sál o rozměrech: délka 26 metrů, šírka 6,8 metru a výška 6,3 metru. Sál byl též využíván pro různé společenské a kulturní akce, používalo se pro něj také označení Národní dům. V budově bylo uskladněno tělocvičné nářadí a za špatného počasí se v ní cvičilo. Za budovou na severní straně bylo zřízeno sportovní hřiště, kde se konala sokolská cvičení v létě a hrála se zde mezi mládeží populární odbíjená. ${ }^{112}$

\section{Činnost českých sokolských jednot na západní Volyni}

Primární činností Sokolů na Volyni byl sportovní nácvik, který se následně prezentoval $\mathrm{v}$ rámci veřejných cvičení. Velký význam pro zkvalitňování výuky měly cvičitelské kurzy. Ve druhé polovině 20. let navštěvovalo několik Čechů z Volyně cvičitelské školy ČOS, jednalo se o Martínka z Kvasilova či Maxu a Kohla ze Zdolbunova. ${ }^{113} \mathrm{Na}$ základě velkého zájmu o cvičitelství, ale také pasových obtíží při vycestování, bylo rozhodnuto o vyslání cvičitele z Československa přímo na Volyň s úkolem vést zde cvičitelský kurz. ${ }^{114} \mathrm{O}$ jeho průběhu referoval pro spolkové periodikum v dubnu 1931 starosta župy J. Zyka: ,Znamenitě se osvědčil např. kurz cvičitelů a cvičitelek sokolských na Volyňsku, kde v 5týdenní škole vychováno 70 cvičitelů a cvičitelek, nejvice z lidi zemědělských, kteřri úspěšně prošli také závěrečnou zkouškou. "115 Zřjejmě jiný cvičitelský kurz (tentokrát pouze čtrnáctidenní) se uskutečnil v roce 1931 v Kvasilově a vedli ho cvičitelé z Československa Karban a Jelínková. ${ }^{116}$ Další z úspěšných cvičitelských kurzů proběhl v roce 1934 v Mirohošti a ř́́dil jej cvičitel František Erben, ${ }^{117}$ zúčastnilo se ho okolo padesáti účastníků. ${ }^{118}$

102 Naše sokolstvo na Volyni v Polsku, Sokol, 1933, roč. 59, č. 8-9.

${ }_{103}$ Tamtéź.

104 Tělesná výchova. Sokol v Kvasilově v Polsku, Lidové noviny, 10. 2. 1926, roč. 34, č. 73, s. 7.

105 Tamtéź.

106 Jaroslav B. ZYKA, Sokolstvo na Volyňsku, Sokol, 1931, roč. 57, č. 4.

107 J. VACULÍK, Dějiny volyňských Čechủ II, s. 30.

${ }_{108}$ Národní muzeum, H8-b. č., anketní popis volyňských obcí, Moldava I.

109 A. KŘIVKA, Kronika sokolské tělocvičné jednoty ve Straklově Českém, s. 3-40.

110 Tamtéž, s. 10

111 Jiří PANCÍŘ - Jindřich ŠÍMA, Hrst vzpomínek na Český Volkov, Lovosice 2005, s. 17 a s. 61

112 J. BONEK - D. MANOVÁ - V. STÁREK, Huleč Česká na Volyni, Žatec 1992, s. 130-131.

${ }_{113}$ Národní muzeum, H8-24083, Sokolská župa zahraniční, 1933, s. 2.

114 Tamtéž, s. 3.

115 J. B. ZYKA, Sokolstvo na Volyňsku, Sokol, 1931, roč. 57, č. 4.

116 M. ŠEREŤUK, Kronika Českého Kvasilova, s. 22.

117 Čilý sokolský ruch na Volyňsku, Věstník Sokolský, 1934, roč. 36, č. 8.

118 František ERBEN, Kurz Volyňského sokolstva, Věstník Sokolský, 1934, roč. 36, č. 12. 


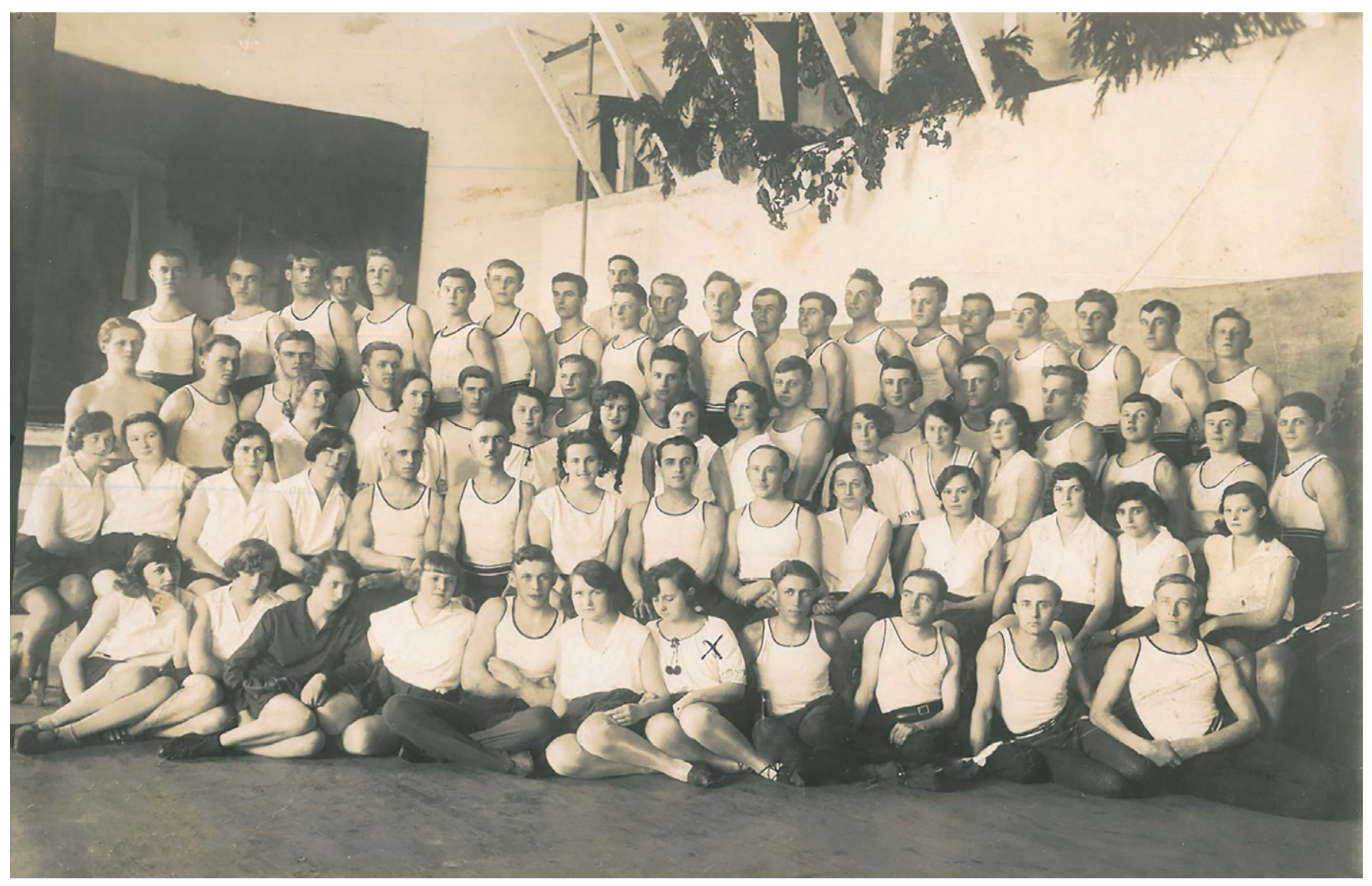

Obr. 8. Účastníci cvičitelského kurzu sokolstva na Volyni, Sbírka Národního muzea

Ve většině jednot se cvičilo zpravidla dvakrát či třikrát týdně. Škála dalších sportovních činností byla v obcích pestrá, v rámci Sokola v Kvasilově či Mirohošti působil například lyžařský odbor, ${ }^{119}$ ve Volkově kromě něj kupříkladu i bruslařský kroužek. ${ }^{120} \mathrm{Na}$ akce do vzdálenějších vesnic se čeští sokolové přepravovali vlaky, žebřinovými vozy a například jednota z Rovna i automobilem. ${ }^{121}$ Velkou událostí byly okrskové „slety“ jednot volyňských Čechů, které se každoročně konaly mezi lety 1933-1937 na konci jara či začátku léta. První z nich se uskutečnily ve dnech 8. a 9. července 1933 v Mirohošti. Tyto velké závody vypsalo náčelnictvo župy zahraniční ČOS. ${ }^{122} \mathrm{Na}$ organizaci akce se podílelo také Ústředí Selských jízd v Praze, volyňským jednotám věnovalo putovní cenu mužů (stř́brný pohár). Na závody přijeli i zástupci této organizace, její místopředseda a poslanec československého Národního shromáždění Pavol Teplanský, který tam pronesl projev. ${ }^{123}$ Putovní cenu určenou pro vítězné družstvo žen, tj. stř́brnou ratolest na podstavci, věnoval $\mathrm{k}$ závodům český poslanec $\mathrm{v}$ polském sejmu V. Meduna. ${ }^{124}$
Závodů se zúčastnilo osm družstev mužů a devět družstev žen. ${ }^{125}$ Mezi muži zvítězil Jaroslav Perný před Mikulášem Martínkem. Medaile pro závodníky věnoval v tomto př́ípadě župní starosta Zyka. ${ }^{126}$

Druhé závody se 8. července 1934 konaly v Hlinsku. Zúčastnilo se jich osm družstev mužů a šest družstev žen. Konala se zde také soutěž jednotlivců o přebor okrsku, do které se zapojilo okolo osmdesáti mužů a žen. Vítězem se v tomto ročníku i v obou letech následujících stal Mikuláš Martínek z Kvasilova, bronzový štít pro vítěze této kategorie daroval generální konzul Svárovský. ${ }^{127}$ Následující závody mužů, žen a dorostu hostil 16. června 1935 Kvasilov, jehož jednota zvítězila mezi sedmi družstvy mužů i čtyřmi žen. Vítězné družstvo dorostenců ze Straklova obdrželo putovní cenu Československé besedy varšavské, kterou byla soška lva, a družstvo dorostenek putovní cenu České matice školské. V tomto př́padě se jednalo o bustu zakladatele Sokola M. Tyrše. ${ }^{128}$ Další okrskové závody za účasti 119 závodníků a závodnic se konaly 31. května 1936 v Kvasilově. ${ }^{129}$

\footnotetext{
119 Národní muzeum, H8-24083, Sokolská župa zahraniční, 1933, s. 3.

120 J. PANCÍŘ - J. ŠÍMA, Hrst vzpominek na Český Volkov, s. 17.

121 A. Kर̌IVKA, Kronika sokolské tělocvičné jednoty ve Straklově Českém, s. 7.

122 Tamtéž.

123 J. PLÁNIČKA, Slavnosti volyňského sokolstva, Věstník Sokolský, 24. 8. 1933, roč. 35, č. 32.

124 A. KŘIVKA, Kronika sokolské tělocvičné jednoty ve Straklově Českém, s. 7.

125 Tamtéž, s. 8.

126 Národní muzeum, H8-24083, Sokolská župa zahraniční, 1933, s. 2.

127 A. KŘIVKA, Kronika sokolské tělocvičné jednoty ve Straklově Českém, s. 10.

128 Tamtéž, s. 19.

129 Tamtéž, s. 29.
} 


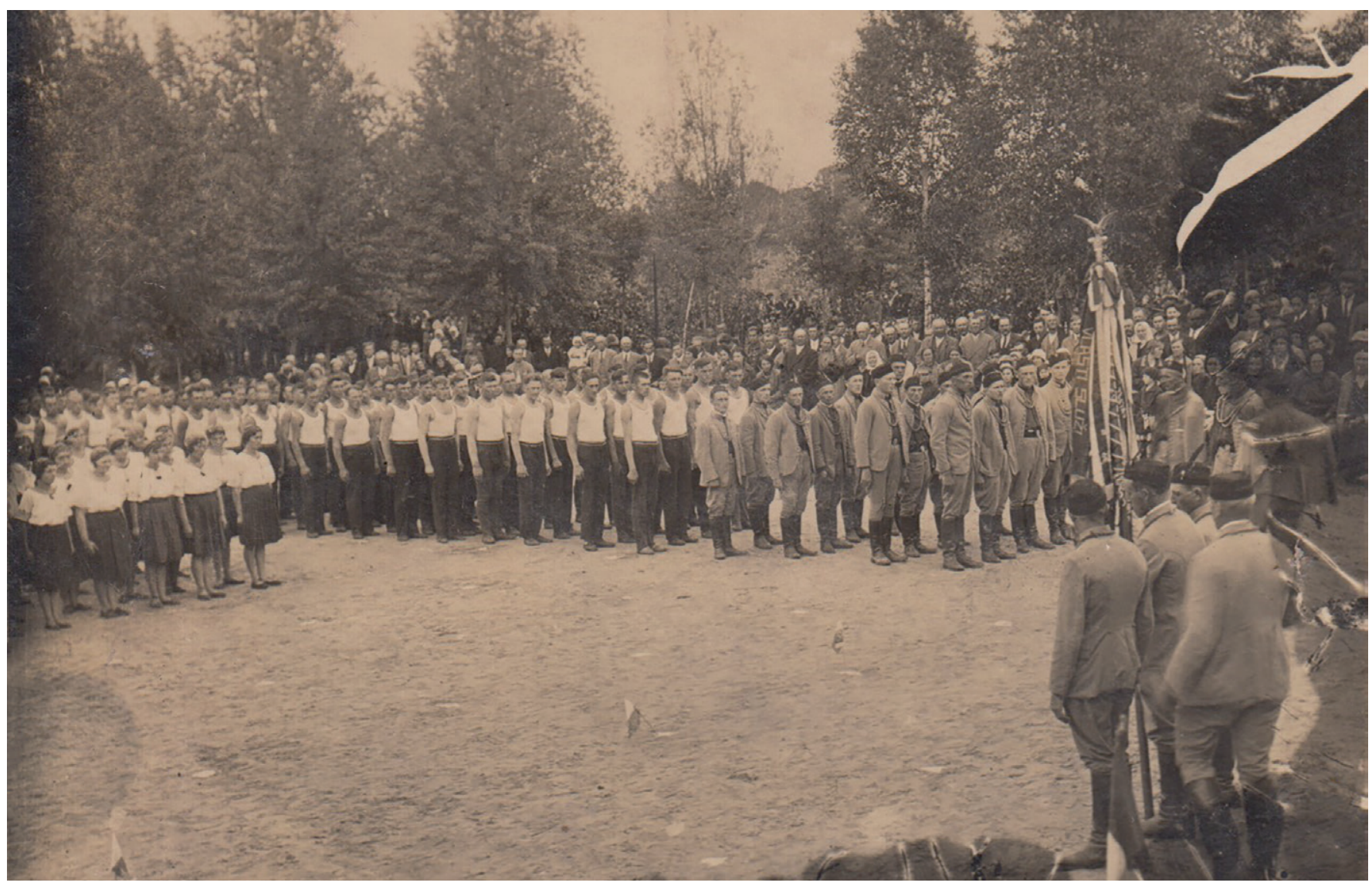

Obr. 9. První velké závody českých jednot v Mirohošti, Sbírka Národního muzea

Poslední závody již v období pozvolného úpadku českých sokolských jednot a za účasti pouze jednoho družstva žen se uskutečnily 20. 6. 1937 v Moldavě. ${ }^{130}$ Následující závody se měly konat 12. června 1938 v Mirohošti, ale kvůli neobdržení povolení z úřadu se nakonec neuskutečnily. ${ }^{131}$

Další významnou událostí pro Čechy z Volyně byly všesokolské slety v Praze, jelikož se při této př́ležitosti výjimečně dostali do staré domoviny. Někteří z nich se jich účastnili už před první světovou válkou, masivnější účast nastala ale až v období meziválečném, kdy do Československa volyňští sokolové cestovali zvláštními vlaky ze stanice Zdolbunov a v průvodu po Praze pak kráčeli pod župou zahraniční. Zájem o účast na sletech v Praze byl enormní, a tak se jich nemohli zúčastnit všichni zájemci, sokolové z řad volyňských Čechů zřejmě dokonce procházeli poměrně náročným výběrem. ${ }^{132}$ Jaroslav Vaculík uvádí, že v roce 1926 výprava z Volyně na všesokolský slet uvítaná v Praze zástupci Národní rady čítala 300 účastníků, ${ }^{133}$ podle okrskového náčelníka Jaroslava Perného se do Prahy vypravilo pouze 120 členů a během následujícího všesokolského sletu v roce 1932 došlo k markantnímu nárůstu účastníků na počet okolo 700 lidí. ${ }^{134} \mathrm{~S}$ velkou pravděpodobností se ale v roce
1932 jednalo o předběžný počet účastníků, který se zřejmě poměrně krátce před akcí kvůli problémům s vydáváním pasů razantně snížil. Nakonec byl skupině volyňských Čechů vydán polský hromadný cestovní pas, jehož součástí jsou i jména a fotografie 176 lidí, kteří cestovali na slet do Prahy. Lidové noviny o př́jezdu výpravy referovaly na titulní straně takto: „Dnes po poledni přijela na Wilsonovo nádraži v Praze výprava volyňských Čechi̊, Sokolů z Polska, $v$ počtu 208 mužu a žen v krojich a s prapory. Výprava byla po celé cestě středem pozornosti. Na nádraži byli mili hosté uvitáni zástupci ministerstva zahraničí, Čs. obce Sokolské a sdružení Čechů a Slováki̊ v zahraničí. "135

V Dějinách volyňských Čechů uvádí Jaroslav Vaculík, že na následujícím, v pořadí již desátém všesokolském sletu v roce 1938 byla přítomna čtyřsetčlenná výprava volyňského okrsku Sokola, ${ }^{136}$ podle jeho novějšího článku se v rámci tohoto sletu jednalo o stočlennou výpravu volyňských Čechů, která přijela do Prahy na dva hromadné cestovní pasy. V rámci cesty musela řešit také velké neprŕijemnosti s převedením měny a do Prahy nakonec přijela fakticky bez finančních prostředků, které jim posléze zapůjčil Československý ústav zahraniční. ${ }^{137}$

130 Tamtéž, s. 35.

131 Tamtéž, s. 46.

132 Miloslav MASOPUST - Věra SUCHOPÁRKOVÁ-SKOŘEPOVÁ, Vzpomínky na rodiště Straklov Český, 1992, s. 18.

133 J. VACULÍK, Déjiny volyňských Čechů II, s. 29.

134 M. ŠEREŤUK, Kronika Českého Kvasilova, s. 22.

135 Sokolští hosté se sjiždějí, Lidové noviny, 1. 7. 1932, roč. 40, č. 331 (odpolední vydání), s. 1.

136 J. VACULÍK, Déjiny volyňských Čechů II, s. 30.

137 J. VACULÍK, Cesta na sokolský slet, Zpravodaj Sdružení Čechů z Volyně a jejich přátel, 1999, roč. 9, č. 4, s. 3. 


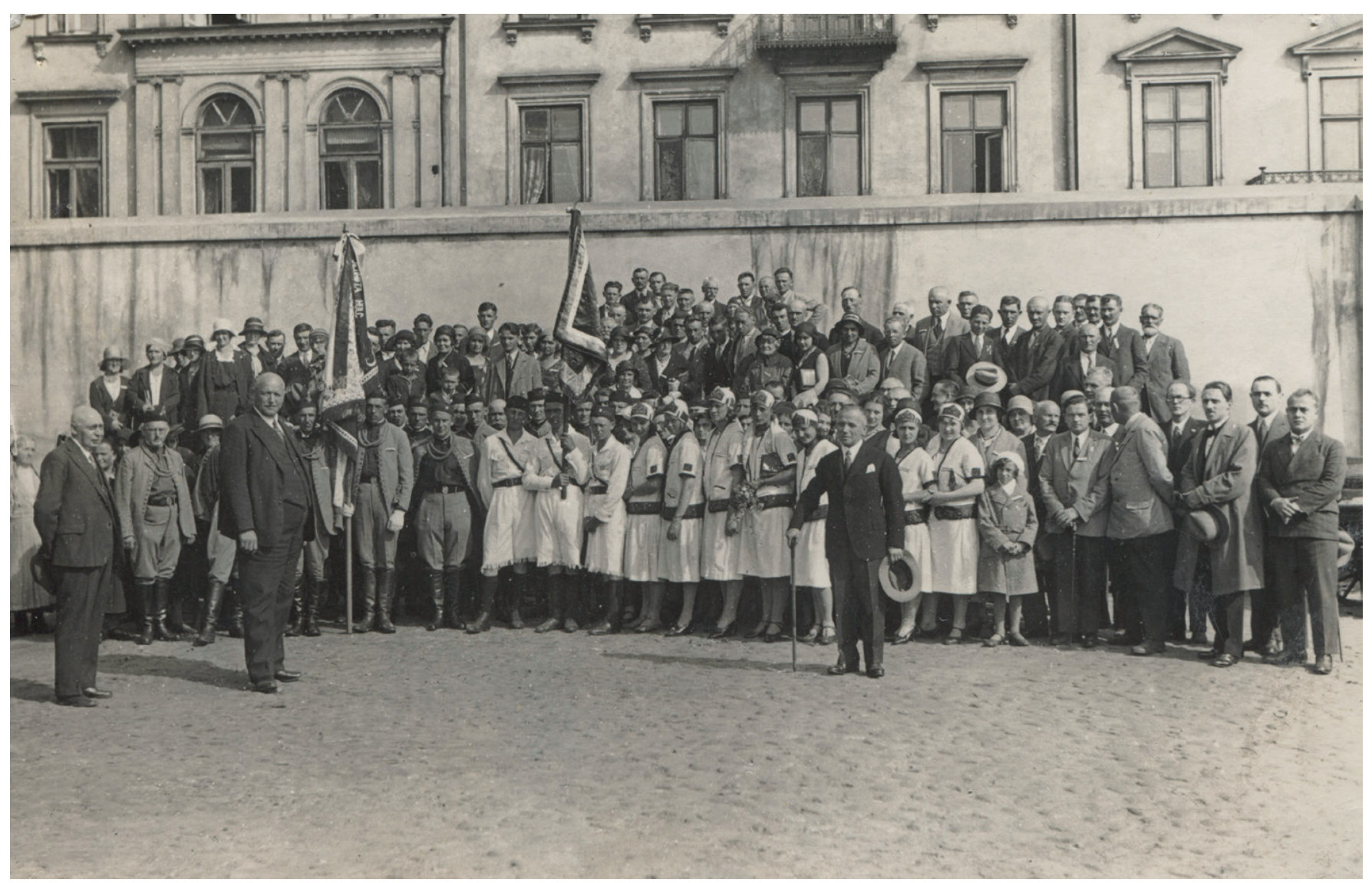

Obr. 10. Češi z Volyně při účasti na všesokolském sletu v roce 1932 v Praze, Sbírka Národního muzea

Tělovýchovná organizace Sokol se neomezovala jen na sportovní činnost, ale ve většině obcí měla především kulturní přesah. Příkladem rozsahu činnosti je působení sokolské jednoty v Straklově. Ta se soustředila i na pořádání divadelních představení (založila si specializovaný divadelní odbor), sokolských akademií, přednášek či různých večírků, např́iklad kabaretních s bohatým programem (cvičení, recitace, zpěv). Díky knihám obdrženým z Československa si založila i sokolskou knihovnu. ${ }^{138} \mathrm{~V}$ dalších obcích byla škála činností obdobná, v Kvasilově i dalších obcích působila $\mathrm{v}$ rámci jednoty také kapela. $\mathrm{V}$ mnoha ohledech se činnost spolků $\mathrm{v}$ obcích prolínala, $\mathrm{v}$ určitých prípadech to mohlo vést i ke sporům viz Kronika Kvasilova: „Dosti dlouhou dobu hasiči hleděli na Sokola nepřiznivě, vidouce v něm jakousi nežádoucí konkurenci, ale nyní pracují svorně “. ${ }^{139} \mathrm{Po}$ většinu času ale Sokol s hasičskými sbory i s jinými spolky, např. s Českou maticí školskou, úspěšně spolupracoval. ${ }^{140}$ Ustavujícího sjezdu Svazu československých spolků v Polsku se sídlem ve Varšavě, který měl zřejmě dále prohlubovat spolupráci mezi organizacemi, se v roce 1931 zúčastnili zástupci minimálně pěti českých sokolských jednot z Rovna, Hulče, Zdolbunova, Kvasilova a Mirohoště. ${ }^{141}$ Význam mělo i personální propojení v rámci různých spolků.
Jedním z důležitých cílů českých sokolských jednot na Volyni byla také snaha o povznášení českého uvědomění a národní hrdosti, o čemž svědčí například vzpomínky pamětníků ze Straklova: ,Sokolská jednota byla zároveň pro naši národnostni menšinu, obklopenou cizím prostředím, duchovním pilírem našeho národního uvědoměni a zdrojem čistého vlastenectví. Podporovala naše vědomí a vztah přináležitosti k naši staré vlasti, $k$ českému národu, k jeho krásným a bohatým tradicím, kultuře a dějinám ". ${ }^{142}$ Autor textu hymny volyňských Čechů Jiří Rébl-Volyňský napsal také „pomyslnou“ hymnu volyňských sokolů ,Vzlet' výše, Sokole!"“, jejíž text byl zveřejněn v poválečném periodiku Věrná stráž. ${ }^{143}$ Některé ze sokolských akcí zejména edukativního přesahu byly pořádány např́íklad 28. října $\mathrm{v}$ den výročí vzniku Československé republiky. Při př́iležitosti př́ijezdu československého vyslance Václava Girsy byly pořádány v Kvasilově či Zdolbunově improvizované sokolské akademie. ${ }^{144}$ Zdolbunovská sokolská jednota např́klad uspořádala koncert s hudbou Antonína Dvořáka, divadelní hry se hrály také často od českých autorů.

\footnotetext{
138 A. KŘIVKA, Kronika sokolské tělocvičné jednoty ve Straklově Českém.

139 J. NÁHLOVSKÝ, Kronika obce Kvasilova, s. 30.

140 J. B. ZYKA, Sokolstvo na Volyňsku, Sokol, 1931, roč. 57, č. 4.

141 J. VACULÍK, Dějiny volyňských Čechů II, s. 45.

${ }_{142}$ M. MASOPUST - V. SUCHOPÁRKOVÁ-SKOŘEPOVÁ, Vzpominky na rodiště Straklov Český, s. 16.

143 Vzlet' výše, Sokole!, Věrná stráž, 2. července 1948, roč. 3, č. 26-27, s. 9.

144 J. VACULÍK, Dëjiny volyňských Čechů II, s. 47.
} 


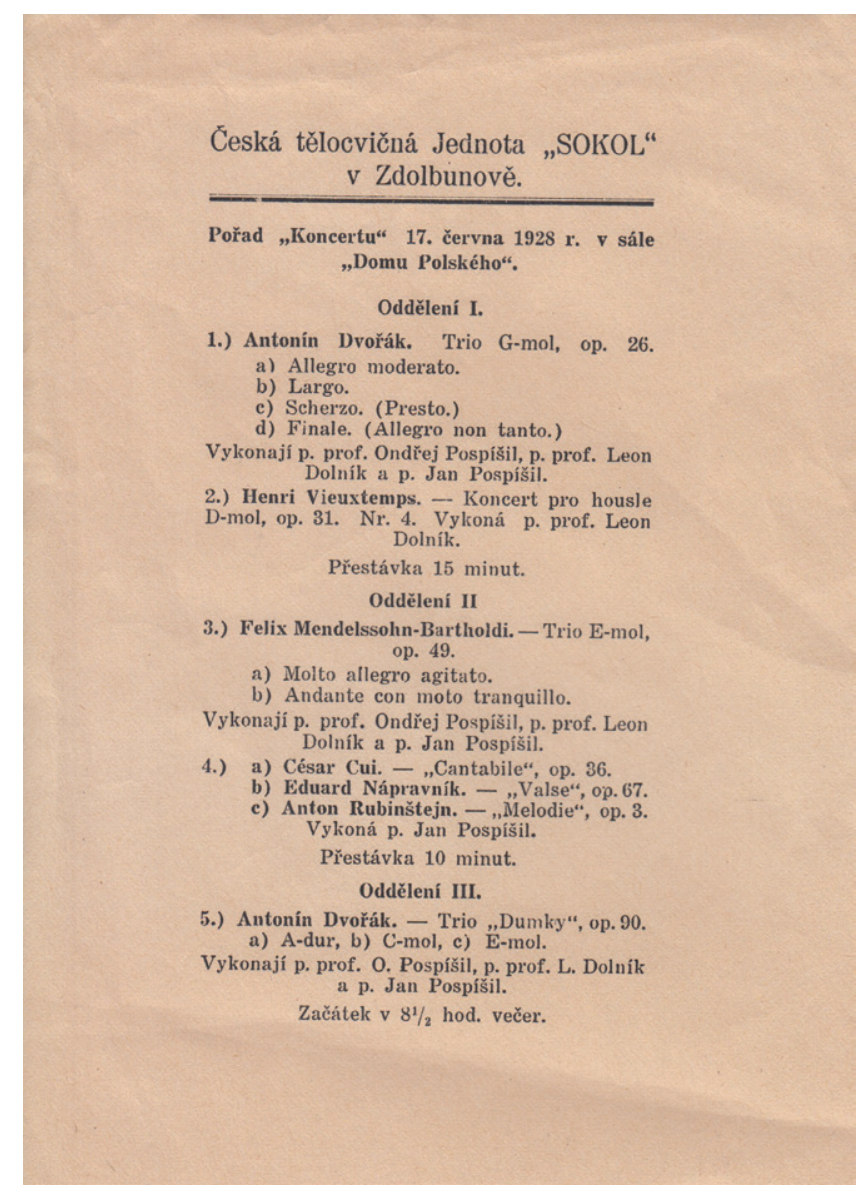

Obr. 11. Pozvánka na koncert pořádaný sokolskou jednotou ve Zdolbunově, Sbírka Národního muzea

\section{Sokolské jednoty v meziválečném období na východní Volyni}

Ve východní (sovětské) části Volyně působilo v meziválečném období o mnoho méně českých sokolských jednot než v západní části oblasti a možnost jejich působení byla po skončení války nuceně jen poměrně krátká. Zájemce o podrobnosti k jejich působení lze odkázat zejména na již zmíněnou publikaci v ukrajinském jazyce Istorija himnastychnoho tovarystva ,Sokil" na Volyni.

Jednota v Krošně České úspěšně fungující již za války navázala na svou činnost, ve vedení Sokola působil Josef Buben a později Ivan Křižánek. ${ }^{145}$ Velký význam měl příchod cvičitele Jaroslava Houšky do oblasti po první světové válce. ${ }^{146}$ Je pravděpodobné, že se mohlo jednat o téhož cvičitele, který před první světovou válkou působil jako cvičitel v Kvasilově. Dne 20. března 1921 byl povolen sokol také v Ovruči v žitomírském újezdu. V tomto období se nadále v celém újezdu markantně zvyšoval počet členů Sokolstva, žitomírské sokolské jednoty se ve zvýšené míře věnovaly i novému sportu v oblasti, tj. fotbalu, v plánu byla také účast na ukrajinské olympiádě. Benefiční aktivity spojené se Sokolem pomáhaly také potřebným v období hladomoru. ${ }^{147}$ Cvičení v Žitomíru probíhalo za příznivého počasí ve venkovních prostorech a $\mathrm{v}$ deštivém počasí v hale knihovny. ${ }^{148}$ Na počátku 20. let si zdejší cvičitel Houška stěžoval na stav vybavení jednoty a snažil se zjednat nápravu. ${ }^{149}$ Sokolská jednota také podle jednoho dokladu jistě fungovala minimálně mezi srpnem 1920 a červencem 1922 v české kolonii Malá Zubovščina, která se nacházela těsně za východní hranicí Volyně již v kyjevské gubernii.

Během roku 1922 nastala $\mathrm{v}$ sovětské části Volyně pro místní krajanské spolky složitá situace, která souvisela se značným potlačováním práv národnostních menšin. Úřady ukončily činnost Sokolů v Okolku, Ovruči, obci Vysoko České a požadovaly zrušení Sokola také v Krošně. Ten byl následně přejmenován, postaven na nové ideologické základy a musel působit pod tamním Komunistickým svazem mládeže. ${ }^{150}$ Podle dochovaných vzpomínek jednoho z pamětníků z Krošny byla sokolská organizace po jejím zrušení místním prezentována jako buržoazní. ${ }^{151}$ Žitomírský cvičitel Houška se po těchto změnách vrátil do Československa. ${ }^{152}$ V Okolku se podařilo zabránit po zrušení jednoty alespoň ztrátě tělocvičného nářadí prohlášením, že ho používá místní hasičský sbor. ${ }^{153}$ Podle dochovaných materií je možné, že během 20. let dále působily v žitomírském regionu Sokoly v českých koloniích ilegálně, takové spolky se mohly nacházet např́íklad v obcích Krušinec či Selenčina. ${ }^{154} \mathrm{~V}$ jedné z odborných studií se objevuje zmínka, že po svém př́ijezdu na Volyň měl vést Sokol v Krošně ještě v roce 1927 později perzekvovaný učitel Antonín Vodsed'álek. ${ }^{155}$

Snahy o založení a rozvíjení Sokola v meziválečném období se staly jedním z důležitých podkladů pro smyšlené spiknutí, kdy měla být pod jeho rouškou šířena mezi českým obyvatelstvem Volyně „,kontrarevoluční nacionalistická organizační činnost"156 a zakládány „české vojensko-povstalecké družiny “. ${ }^{157}$ Protokol o popravě finančního inspektora Holana z roku 1938 ze zasedání „trojky“ při Lidovém komisariátu vnitřních záležitostí (NKVD) například uváděl, že mezi lety 1920 a 1930 byl členem „,̌eské nacionálně-šovinistické organizace Sokol“ “ ${ }^{158} \mathrm{Na}$ počátku roku 1938 byli téměř všichni v oblasti dříve působící významní

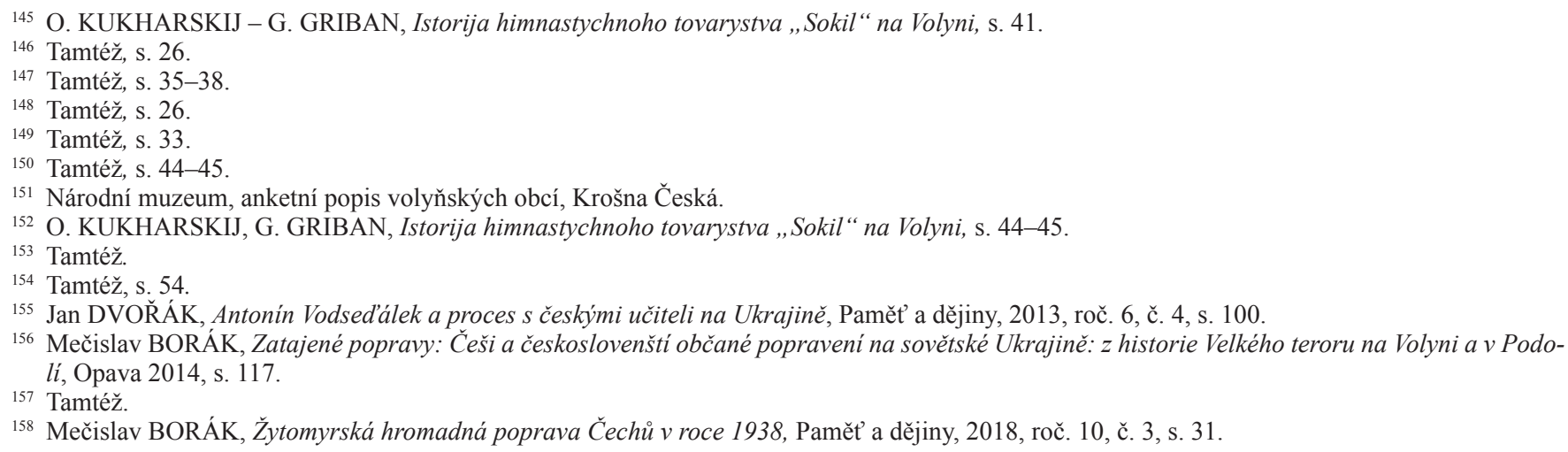




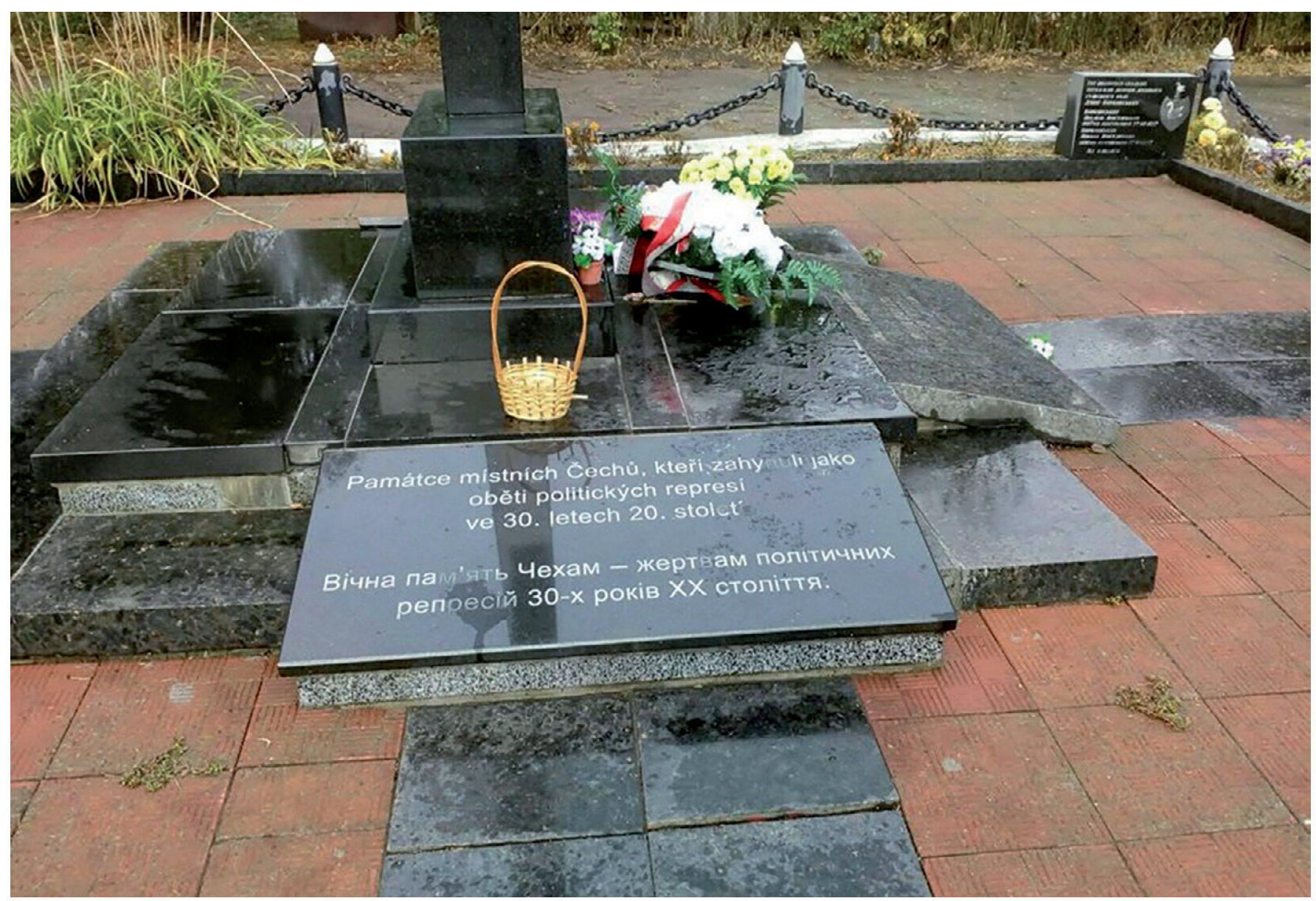

Obr. 12. Památník obětí politických perzekucí v místě jejich popravy v Žitomíru, foto Ondřej Štěpánek

činovníci českých Sokolů zatčeni. Část z nich byla odeslána na Sibiřr, ${ }^{159}$ další údajní spiklenci byli po velkém procesu dne 28. záŕi 1938 zastřeleni, mezi 78 Čechy i řada sokolů, včetně prvního cvičitele Sokola v Krošně České Štefana Tomana. ${ }^{160}$

Na místě této popravy i dalších tragických událostí na kraji města Žitomír se nachází pietní místo. To je od září 2014 věnováno také památce místních Čechů, kteří zahynuli jako oběti politických represí ve 30 . letech 20 . století.

\section{Druhá světová válka}

Činnost většiny sokolských jednot v polské části Volyně přerušily události, které bezprostředně předcházely druhé světové válce, nebo až válka samotná. Např́íklad straklovská jednota měla své pravděpodobně poslední veřejné cvičení ještě 28. srpna 1939. ${ }^{161} \mathrm{~V}$ některých obcích sokolské aktivity pokračovaly zřejmě i zkraje druhé světové války, v České Hulči se konaly sokolské akademie i za první vlády Sovětů mezi lety 1939-1941, následně zde organizování kultury ustalo, zábavy byly zakázány a ani Sokol nevyvíjel činnost. ${ }^{162}$ Zpočátku války měla důležitou funkci sokolovna v Kvasilově poskytnutá místní jednotou. Sloužila jako ubytovací kapacita pro desítky osob z tvořící se vojenské skupiny (než nastalo chladné počasí) a později jako jídelna. ${ }^{163}$ Řada českých mužů činných v Sokolech vstoupila do československé armády a přišla s ní do Československa. Mnozí z nich dosáhli v armádě vysokých hodností, např́klad jako velitel vojenské skupiny Žatec působil ještě po skončení války dřivější sokolský okrskový náčelník Jaroslav Perný. Československou armádou prošly také stovky žen. Zřejmě jako vůbec první volyňská Češka vstoupila do československého praporu Jiřina Somolová-Predmerská. ${ }^{164}$ Součástí sbírek Národního muzea se postupně stal její battledress už z prvního vybavení v Buzuluku anglickými uniformami i její sokolské dorostenecké šaty používané v oblasti Volyně ve 30. letech 20. století. Někteří sokolové z řad volyňských Čechů, včetně výrazných osobností, byli mezi stovkami obětí různých tragických událostí druhé světové války, zejména válečných bojů. Za reflektování stojí také osud již vzpomenutého volyňského rodáka Otakara Klicha, tento prokurista

159 O. KUKHARSKIJ - G. GRIBAN, Istorija himnastychnoho tovarystva „,Sokil“ na Volyni, s. 54.

160 Tamtéž

161 A. KŘIVKA, Kronika sokolské tělocvičné jednoty ve Straklově Českém, s. 52.

162 J. BONEK - D. MANOVÁ - V. STÁREK, Huleč Česká na Volyni, s. 169.

${ }^{163}$ Roman ŠTÉR, Československá vojenská emigrace na Volyni 1939-1940; Nástin historie kvasilovské skupiny, bakalářská práce, Univerzita Karlova, Praha 2017, s. 30-31.

164 Roman ŠTÉR, Volyňské ženy v československých vojenských jednotkách na východni frontě, Sborník prací Masarykovy univerzity, řada společenských věd, Brno 2015/2, s. 48. 


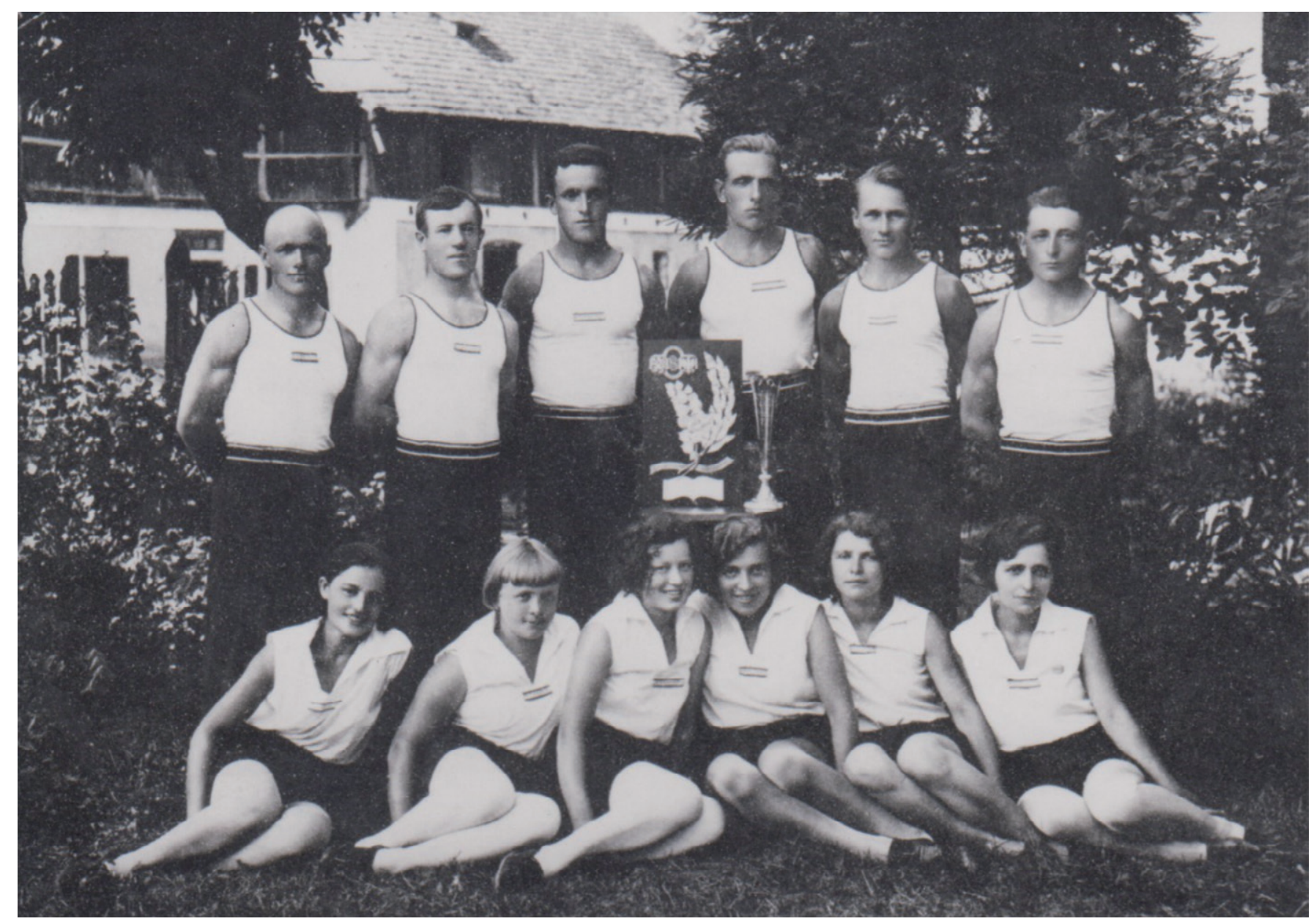

Obr. 13. Součástí sbírek Národního muzea jsou putovní ceny vítězných družstev mužů a žen z této fotografie. Sbírka Národního muzea

se stal náčelníkem pražské župy Scheinerovy a v roce 1941 dokonce načas hlavou sokolského odboje v protektorátu, ${ }^{165}$ což vedlo k jeho zatčení a deportaci do Osvětimi, kde v následujícím roce zemřel.

\section{Zachovaná pamět' působení Sokolů na Volyni}

Po konci druhé světové války sokolské jednoty Čechů na Volyni nebyly obnoveny. Ve Věrné stráži si stěžovala v roce 1947 O. Kadavá na nezájem o zapojení „,volyňákư“ do Sokolů po reemigraci v Československu a dále v textu je pak burcovala k aktivitě vzhledem k blížícímu se sletu: „Dnes mnozi z těch, kteři na Volyni byli vzornými Sokoly, vrátili se do ,staré vlasti', ale bohužel do Sokola nechodí. V̌̌ude k tomu nejsou podmínky, to plně chápu. Ale vím, že jsou mnozí, kteři by cvičit mohli, ale snad se jim zdá, že sestárli, zvážněli a že se to už pro ně ženaté nebo vdané nehodí, prohánět se na cvičeni ". ${ }^{166}$ Řada Čechů z Volyně se však do činnosti československých sokolských jednot zapojila, např́iklad sokolové z Kvasilova působili zejména v tělovýchovné jednotě Liběšice-Trnavany Sladkovského župy. Někteři Češi vrátivší se z Volyně se zúčastnili také v pořadí jedenáctého a po více než čtyři desetiletí posledního všesokolského sletu v roce 1948, jejich počet se ovšem neevidoval. Do Československa byla během reemigračních akcí prrivezena vlaky z Volyně také část tělocvičného nářadí. Náčiní původně patřící kvasilovské jednotě krátce sloužilo jednotě v Liběšicích, po jejím zrušení bylo převedeno do majetku škol a jednot v bývalém okrese Žatec. ${ }^{167}$

Důležitým symbolem sokolských jednot byly jejich prapory. Jeden z prvních praporů volyňských jednot měl být vyroben u př́ležitosti stého výročí narození zakladatele Sokola Tyrše, tj. v roce $1932 .{ }^{168}$ Zřejmě se jednalo o prapor kvasilovský, jehož kmotrem byl starosta Svazu polského sokolstva Adam Zamoyski a jeho kmotrou měla být Hana Benešová, manželka pozdějšího prezidenta Edvarda Beneše. ${ }^{169}$ Prapor byl darovaný jednotě spolkem „České srdce“ a následně ho kvasilovské sokolky doplnily vyšitým názvem jednoty a rokem založení. ${ }^{170}$ Cestou na polský sokolský slet ve Varšavě se setkal starosta kvasilovské jednoty

\footnotetext{
165 Jan B. Uhlí̌́, Sokol za protektorátu. Organizovaná rezistence ČOS, disertační práce, Univerzita Karlova, 2005, s. 72.

166 O. KADAVÁ, ,,Spějme dál... “, Věrná stráž, 16. dubna 1947, roč. 2, č. 14-15, s. 11.

167 M. ŠEREŤUK, Kronika Českého Kvasilova, s. 23.

168 Polská účast na všesokolském sletě, Národní listy, 19. 6. 1932, roč. 72, č. 169, s. 9.

169 Československé sokolstvo za hranicemi, Věstník Sokolský, 6. 10. 1932, roč. 34, č. 36

170 M. ŠEREŤUK, Kronika Českého Kvasilova, s. 22.
} 
Svárovský s maršálem Pilsudským, který si prapor prohlédl a jeho pobočník na žerd' praporu připevnil zvláštní štítek. ${ }^{171}$ Nedlouho po začátku druhé světové války v březnu 1940 tři členové jednoty Sokola Kvasilov měli předat prapor jednoty doplněný o novou stuhu s nápisem „Byli jsme a budem“, aby mohl být donesen do osvobozené vlasti. ${ }^{172} \mathrm{~V}$ současnosti je uložen v Regionálním muzeu Karla Aloise Polánka v Žatci. ${ }^{173}$ Prapor obnovené jednoty v Mirohošti pocházející zřejmě z roku 1931 je součástí fondu volyňských Čechů ve sbírkách Oddělení novodobých českých dějin Národního muzea. Je vyšitý podle návrhu učitele Kozáka a obsahuje nápis „Mirohoštánek dar své jednotě“. Ve středním poli se nachází ozdobně vyšité slovo Sokol v červenobílém poli. $\mathrm{Z}$ dalších zajímavých textilních předmětů jsou v depozitárrích muzea také dva sokolské stejnokroje, které však nejsou opatřeny původními volyňskými domovenkami. Původními vlastníky byli pánové Větrovec a Jelínek, který se ve stejnokroji zúčastnil i všesokolských sletů v Praze v letech 1938 a 1948.

Upomínkou na závody na Volyni je červené startovní číslo „99“ na hrubém plátně původně patřící Jiřímu Gabrielovi (ze soutěže v Kvasilově v roce 1936), diplomy ze závodů a unikátem ve sbírkách instituce jsou v textu zmíněné putovní ceny ze závodů volyňských Čechů. Pohár ze zápolení mužů byl vyroben v Praze 28. října 1932 Františkem Javůrkem a Josefem Vrabcem. Jsou na něm vyryty názvy vítězných jednot v jednotlivých ročnících závodů, tj. 1933 Kvasilov, 1934 Mirohošt', 1935 Kvasilov, 1936 Mirohošt'. O plaketu doplněnou dvěma ratolestmi věnovanou poslancem polského sejmu Medunou soupeřila družstva žen. Je doplněna o nápis: „V sesterském zápolu k metě nejvyšší“.
Ve spodní části jsou taktéž vyryta totožná vítězná družstva z jednotlivých ročníků závodů jen s výjimkou roku 1934, kdy v závodě zvítězily ženy z města Dubno. Šest zbývajících předepsaných polí zůstalo navždy nevyplněno. V Národním muzeu jsou uchovávány spolkové a sletové průkazy či desítky fotografií. Sokolské fotografie jsou také součástí fondu volyňských Čechů v Národním archivu. Některé z výše uvedených předmětů by $\mathrm{v}$ budoucnu měly rozšírit expozici Čechů z Volyně dislokovanou v Podbořanech.

V rámci shrnutí lze uvést, že sokolské jednoty na Volyni byly důležitou součástí spolkového života Čechů žijících v oblasti. Kromě rozvíjení tělesné zdatnosti pomáhaly též s výchovou mládeže a posilováním českého vědomí i sounáležitosti s historickou vlastí. Přestože jejich působení bylo v delších obdobích komplikováno a znemožňováno polskými i sovětskými úřady, zanechaly důležitou stopu, na kterou se leckde v regionu stále vzpomíná a na kterou v něm navazují spolky i v současnosti. Sokol v Kvasilově navázal na své historické kořeny a je $\mathrm{v}$ současnosti podle dostupných informací znovu aktivní. V bývalé východní Volyni jsou prripomínány české kořeny místní tělovýchovy v úvodu expozice „Galerie sportovní slávy“ v Žitomírské státní univerzitě I. Franka. U př́ležitosti stopátého výročí vzniku Sokola v Žitomíru byla za početné účasti místních obyvatel na fasádě této univerzity odhalena také pamětní deska, která nese nápis v ukrajinštině: ,,V této budově II. mužského gymnázia ke konci roku 1910 byl Čechy založen a svoji činnost začal volyňský gymnastický spolek Sokol.“ Odhalení desky doprovázela slavnostní hymna a pochod sokolů „Lví silou“ v úpravě českého kapelníka Františka Kmocha doplněná zpěvem místních obyvatel s českými kořeny.

171 Tamtéž.

172 R. ŠTÉR, Československá vojenská emigrace na Volyni 1939-1940; Nástin historie kvasilovské skupiny, bakalářská práce, Univerzita Karlova, s. 66 .

173 M. ŠEREŤUK, Kronika Českého Kvasilova, s. 23. 